\title{
Highly efficient benzodifuran based ruthenium sensitizers for thin-film dye- sensitized solar cells
}

\author{
Mariusz J. Bosiak ${ }^{\dagger *}$, Marcin Rakowiecki ${ }^{\dagger}$, Andrzej Wolan ${ }^{\dagger}$, Jolanta Szlachta ${ }^{\ddagger}$, Edyta Stanek ${ }^{\ddagger}$, \\ Dawid Cycoń $^{\ddagger}$, Krzysztof Skupień ${ }^{\S}$ \\ ${ }^{\dagger}$ Synthex Technologies Sp. z o.o., Gagarina 7, 87-100 Toruń, Poland \\ ${ }^{\ddagger}$ ML System, Warszawska 50 d, 35-230 Rzeszów, Poland

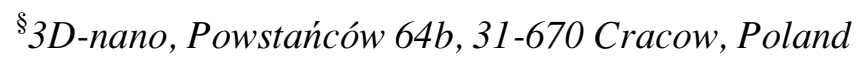

Keywords:

DSSC

Benzodifuran

The Sonogashira reaction

Ruthenium dyes

Solar cells

* Corresponding author: Tel.: +48 512038649; fax: +48 56 6542477; e-mail: bosiak@synthex.com.pl 


\section{Introduction}

Since 1991 when O'Regan and Grätzel [1] described the first dye-sensitized solar cell (DSSC) containing ruthenium dye as a photosensitizer, this technology have attracted tremendous interest due to its low manufacturing cost, a remarkable stability, and respectable high solar-to-electric energy conversion efficiency $(\eta)$ up to $12 \%$ [2]. Although the perovskite type sensitizers derived from lead halides and applied by spin coating technique allowed to reach the efficiency of $\sim 19.3 \%$ [3], there is still place for organic ruthenium dyes soluble in "green" organic solvents, such as ethanol, and easily applicable by "dip coating" or "flow dyeing" techniques, well suited for the preparation of large area solar panels.

The first commonly used homoleptic ruthenium complexes for DSSC applications (N3 and N719) developed in Grätzel group [4,5] revealed $\eta \sim 11 \%$ for devices based on these dyes under one-sun illumination (Fig. 3) [6,7] The main drawback of the devices was their low stability. To improve their durability an amphiphilic ruthenium sensitizer Z907 was developed by replacing one 4,4'-dicarboxylic-2,2'-bipyridine (dcbpy) ligand in the $\mathbf{N 3}$ dye with an ancillary 4,4'-dinonyl-2,2'bipyridine ligand [8-10]. Although stability of the device based on Z907 improved significantly, the efficiency decreased, mainly due to lower light-harvesting, related to the molar extinction 
coefficient for two UV-Vis absorption bands - at 350-450 nm (ligand-centered charge transfer (LCCT) transitions $\left(\pi-\pi^{*}\right)$ ), as well as at 500-600 $\mathrm{nm}$ (metal-to-ligand charge transfer (MLCT) transitions $\left.\left(4 \mathrm{~d}-\pi^{*}\right)\right)$. To improve the light-harvesting efficiency via an enhanced molar extinction coefficient, many heteroleptic ruthenium complexes derived from 2,2'-bipyridine substituted with aryl, heteroaryl and aryl-vinyl groups were developed [11-25]. Herein, the synthesis and photovoltaic characterization of benzodifuran (BDF) derived ruthenium dyes of high energy conversion efficiency is described.

\section{Experimental}

\subsection{Materials and general methods}

Experiments with air and moisture sensitive materials were carried under argon atmosphere. Glassware was oven dried for several hours, assembled hot, and cooled in a stream of argon. Silica gel 60, Merck 230-400 mesh, was used for preparative column flash chromatography. Analytical TLC was performed using Sigma-Aldrich silica gel on TLC Al foils with fluorescent indicator 254 $\mathrm{nm}, \quad 0.2 \mathrm{~mm}$ plates. 1-Octanol, iodine, morpholine, 4,4'-dibromo-2,2'-bipyridine, [1,1'bis(diphenylphosphino)ferrocene]dichloropalladium(II), copper iodide, diisopropylamine, ethynyltrimethylsilane, $1 \mathrm{M}$ tetrabutylammonium fluoride solution in THF, dichloro( $p$ cymene)ruthenium(II) dimer, 2,2'-bipyridine-4,4'-dicarboxylic acid, ammonium thiocyanate, and tetrabutylammonium hydroxide were commercially available from Sigma-Aldrich, Merck or Fluorochem, and were used without further purification. [2,2'-Bipyridine]-4,4'-dicarbaldehyde was prepared according to the literature procedure [26]. Solvents were purchased from Avantor and Sigma-Aldrich. Toluene was distilled from sodium benzophenone ketyl prior to use, DMF was stirred overnight with calcium hydride, filtered, distilled at $20 \mathrm{mmHg}$, and stored over 4A molecular sieves. Chloroform, diethyl ether, methanol, anhydrous ethanol, THF, $n$-heptane, and ethyl acetate were used without further purification. Deuterated solvents for NMR spectroscopy were purchased from Sigma-Aldrich. Sephadex LH-20 was purchased from GE Healthcare. N719 and Z907 dyes 
were purchased from Dyesol. Melting points were determined with a Büchi SMP 32 and Barnstead-

Thermolyne Mel-Temp II apparatus in open capillaries and are uncorrected. Elemental analyses were performed at Elementary Analysensysteme GmbH Vario MACRO CHN analyzer.

\subsubsection{Spectroscopic measurements}

${ }^{1} \mathrm{H}$ and ${ }^{13} \mathrm{C}$ NMR spectra were recorded on a Bruker Advance III $400 \mathrm{MHz}$ or Bruker Advance III $700 \mathrm{MHz}$ instrument at ambient temperature. Chemical shifts are reported in parts per million ( $\delta$ scale), coupling constants ( $J$ values) are listed in Hertz. Anhydrous ethanol (spectrometric grade from Sigma-Aldrich) was employed as solvent for absorption measurements. $\mathrm{UV} / \mathrm{Vis}$ absorption spectra of dyes solutions and sensitized $\mathrm{TiO}_{2}$ films were recorded by means of a Jasco V670 UV-Vis-NIR spectrophotometer equipped with liquid a cell holder (10 mm quartz cell, versus solvent blank) and thin film holder. IR spectra were recorded on a Perkin Elmer FT-IR Spectrum Two spectrometer equipped in diamant ATR.

\subsection{Synthesis of the compounds}

\subsubsection{Ethyl 5-hydroxy-2-methylbenzofuran-3-carboxylate (1)}

A solution of $p$-benzoquinone $(54.045 \mathrm{~g}, 0.5 \mathrm{~mol})$ and ethyl acetoacetate $(200 \mathrm{~mL}, 1.583$ mol) in dry acetone $(200 \mathrm{~mL})$ was added dropwise during $9 \mathrm{~h}$ to a mechanically stirred solution of anhydrous zinc chloride $(70 \mathrm{~g}, 0.513 \mathrm{~mol})$ in acetone $(100 \mathrm{~mL})$ and acetic acid $(5 \mathrm{~mL})$ at $75{ }^{\circ} \mathrm{C}$. The mixture was stirred for additional $10 \mathrm{~min}$., transferred into a large crystallizer and left opened in fume cupboard overnight. The crystallizer was transferred into freezer and left for $24 \mathrm{~h}$. Precipitate was filtered off, washed with cold $\mathrm{MeOH}(2 \times 50 \mathrm{~mL})$ and dried on air. Crude product was crystallized from toluene to give $47.50 \mathrm{~g}(43 \%)$ of white solid, mp=143-144 ${ }^{\circ} \mathrm{C}$. Lit. [27] 143.5-144 ${ }^{\circ} \mathrm{C} .{ }^{1} \mathrm{H}$ NMR $\left(700 \mathrm{MHz}, \mathrm{CDCl}_{3}\right) ; \delta \mathrm{ppm}: 1.41\left(\mathrm{t}, J=7 \mathrm{~Hz}, 3 \mathrm{H}, \mathrm{CH}_{3}\right), 2.71\left(\mathrm{~s}, 3 \mathrm{H}, \mathrm{CH}_{3}\right), 4.38$ (q, $J=7 \mathrm{~Hz}, 2 \mathrm{H}, \mathrm{CH}), 6.79-6.80\left(\mathrm{dd}, J=9.1 \mathrm{~Hz}, J=2.8 \mathrm{~Hz}, 2 \mathrm{H}, \mathrm{CH}_{2}\right), 5.88(\mathrm{~s}, 1 \mathrm{H}, \mathrm{CH}), 7.24$ (d, $J=4.2$ $\mathrm{Hz}, 1 \mathrm{H}, \mathrm{CH}), 7.26(\mathrm{~s}, 1 \mathrm{H}, \mathrm{CH}), 7.48(\mathrm{~d}, J=2.8,1 \mathrm{H}, \mathrm{CH}) .{ }^{13} \mathrm{C} \mathrm{NMR}\left(\mathrm{CDCl}_{3}, 175 \mathrm{MHz}\right) ; \delta \mathrm{ppm}$ : $15.38\left(\mathrm{CH}_{3}\right), 15.75\left(\mathrm{CH}_{3}\right), 61.53\left(\mathrm{CH}_{2}\right), 107.84(\mathrm{CH}), 109.86(\mathrm{C}), 112.25(\mathrm{CH}), 113.72(\mathrm{CH})$, 
128.26 (C), 149.52 (C), 153.67 (C), 165.52 (C), 165.86 (C). IR (ATR) $v_{\max } \mathrm{cm}^{-1}: 3323,1668,1623$ $1607,1580,1475,1464,1417,1382,1348,1300,1259,1217,1168,1111,1087,1027,954,866$, 853, 838, 809, 784, 736, 682, 652, 617, 573. Anal. Calcd. for $\mathrm{C}_{12} \mathrm{H}_{12} \mathrm{O}_{4}: \mathrm{C}, 65.45 ; \mathrm{H}, 5.49$. Found: C, 65.61; H, 5.44 .

\subsubsection{Octyl 5-hydroxy-2-methylbenzofuran-3-carboxylate (2)}

To a dispersion of ethyl 5-hydroxy-2-methylbenzofuran-3-carboxylate (29.54 g, $134 \mathrm{mmol})$ in 1-octanol $(300 \mathrm{~mL})$, concentrated sulfuric acid $(1 \mathrm{~mL})$ was added and the mixture was heated to $150^{\circ} \mathrm{C}$ in opened flask and stirred at this temperature for $18 \mathrm{~h}$. It was poured into concentrated solution of sodium bicarbonate $(200 \mathrm{~mL})$ and brine $(100 \mathrm{~mL})$, stirred for several minutes and extracted with ethyl acetate $(3 \times 100 \mathrm{~mL})$. Combined organic layers were dried with anhydrous magnesium sulfate. The ethyl acetate was removed using rotary evaporator and the remaining 1octanol was distilled off under reduced pressure. To a slurry $n$-heptane $(500 \mathrm{~mL})$ was added, the mixture was heated to reflux and filtered through a warm Büchner funnel. The filtrate was cooled overnight and the flaky precipitate was filtered off and dried to obtain $32.87 \mathrm{~g}(80 \%)$ of pure solid, mp 93-94 ${ }^{\circ} \mathrm{C} .{ }^{1} \mathrm{H}$ NMR $\left(\mathrm{CDCl}_{3}, 400 \mathrm{MHz}\right) ; \delta$ ppm: $0.90\left(\mathrm{t}, J=6.8 \mathrm{~Hz}, 3 \mathrm{H}, \mathrm{CH}_{3}\right), 1.28-1.42(\mathrm{~m}, 8 \mathrm{H}$, $\left.4 \mathrm{CH}_{2}\right), 1.45-1.52\left(\mathrm{~m}, 2 \mathrm{H}, \mathrm{CH}_{2}\right), 1.78-1.86\left(\mathrm{~m}, 2 \mathrm{H}, \mathrm{CH}_{2}\right), 2.76\left(\mathrm{~s}, 3 \mathrm{H}, \mathrm{CH}_{3}\right), 4.36(\mathrm{t}, J=6.8 \mathrm{~Hz}, 2 \mathrm{H}$, $\left.\mathrm{CH}_{2}\right), 5.23(\mathrm{~s}, 1 \mathrm{H}, \mathrm{OH}), 6.82\left(\mathrm{dd}, J=8.8 \mathrm{~Hz}, J=2.6 \mathrm{~Hz}, 1 \mathrm{H}, \mathrm{CH}_{\mathrm{Ar}}\right), 7.30\left(\mathrm{~d}, J=8.8 \mathrm{~Hz}, 1 \mathrm{H}, \mathrm{CH}_{\mathrm{Ar}}\right)$, $7.46\left(\mathrm{~m}, 1 \mathrm{H}, \mathrm{CH}_{\mathrm{Ar}}\right) .{ }^{13} \mathrm{C} \mathrm{NMR}\left(\mathrm{CDCl}_{3}, 100 \mathrm{MHz}\right) ; \delta \mathrm{ppm}: 14.07\left(\mathrm{CH}_{3}\right), 14.81\left(\mathrm{CH}_{3}\right), 22.63\left(\mathrm{CH}_{2}\right)$, $26.10\left(\mathrm{CH}_{2}\right), 28.73\left(\mathrm{CH}_{2}\right), 29.19\left(\mathrm{CH}_{2}\right), 29.22\left(\mathrm{CH}_{2}\right), 31.78\left(\mathrm{CH}_{2}\right), 64.82\left(\mathrm{CH}_{2}\right), 106.81(\mathrm{CH})$, $108.90(\mathrm{C}), 111.25(\mathrm{CH}), 112.79(\mathrm{CH}), 127.31(\mathrm{C}), 148.50(\mathrm{C}), 152.85(\mathrm{C}), 164.38(\mathrm{C}), 165.07(\mathrm{C})$. IR (ATR) $v_{\max } \mathrm{cm}^{-1}: 3348,2948,2923,2854,1670,1622,1605,1577,1463,1415,1394,1382$, $1359,1298,1268,1258,1212,1173,1111,1094,1020,962,944,863,837,806,789,783,735$, 724, 648, 619, 611, 581. Anal. Calcd. for $\mathrm{C}_{18} \mathrm{H}_{24} \mathrm{O}_{4}$ : C, 71.03; H, 7.95. Found: C, 71.21; H, 7.97. 


\subsubsection{Ethyl 5-hydroxy-6-iodo-2-methylbenzofuran-3-carboxylate (3)}

Ethyl 5-hydroxy-2-methylbenzofuran-3-carboxylate (1) (26.43 g, $120 \mathrm{mmol})$ and iodine (48.72 g, $192 \mathrm{mmol}, 1.6$ equiv.) were dispersed in anhydrous methanol (100 mL) and stirred for 5 min. under argon. The mixture was cooled to $0^{\circ} \mathrm{C}$, and morpholine (30.32 g, $348 \mathrm{mmol}, 2.9$ equiv.) was added dropwise at a rate to keep the temperature below $30^{\circ} \mathrm{C}$, slowly heated to $35^{\circ} \mathrm{C}$, and stirred at this temperature for $120 \mathrm{~h}$. Water $(20 \mathrm{~mL})$ was added and the mixture was left at $-20^{\circ} \mathrm{C}$ overnight. Precipitate was filtered off, washed with cold methanol of $\left(-25^{\circ} \mathrm{C}, 3 \times 60 \mathrm{~mL}\right)$, and dried to obtain $46.91 \mathrm{~g}$ of beige solid. It was extracted with diethyl ether $(450 \mathrm{~mL})$ using a Soxhlet extractor for $48 \mathrm{~h}$. The crude product was finally crystallized from methanol to obtain $13.97 \mathrm{~g}$ (34 $\%)$ of pure white solid, $\mathrm{mp}=196-197^{\circ} \mathrm{C}$. Lit. [27] $194-194.5{ }^{\circ} \mathrm{C} .{ }^{1} \mathrm{H}$ NMR $\left(\mathrm{CDCl}_{3}, 700 \mathrm{MHz}\right) ; \delta$ ppm: 1.44 (t, J=7.2 Hz, 3H, $\left.\mathrm{CH}_{3}\right), 2.73\left(\mathrm{~s}, 3 \mathrm{H}, \mathrm{CH}_{3}\right), 4.40$ (q, J=7.2 Hz, 2H, $\left.\mathrm{CH}_{2}\right), 5.28(\mathrm{~s}, 1 \mathrm{H}, \mathrm{OH})$, $7.56\left(\mathrm{~s}, 1 \mathrm{H}, \mathrm{CH}_{\mathrm{Ar}}\right), 7.73\left(\mathrm{~s}, 1 \mathrm{H}, \mathrm{CH}_{\mathrm{Ar}}\right) .{ }^{13} \mathrm{C} \mathrm{NMR}\left(\mathrm{CDCl}_{3}, 100 \mathrm{MHz}\right) ; \delta \mathrm{ppm}: 14.42\left(\mathrm{CH}_{3}\right), 14.56$ $\left(\mathrm{CH}_{3}\right), 60.47\left(\mathrm{CH}_{2}\right), 80.68(\mathrm{C}), 106.25(\mathrm{CH}), 108.98(\mathrm{C}), 119.63(\mathrm{CH}), 128.38(\mathrm{C}), 148.73(\mathrm{C})$, 151.25 (C), $164.11(\mathrm{C}), 165.11$ (C). IR (ATR) $v_{\max } \mathrm{cm}^{-1}: 3255,1672,1614,1582,1447,1405,1380$ $1345,1279,1268,1183,1166,1150,1115,1093,1033,964,909,862,841,800,786,722,657$, 590. Anal. Calcd. for $\mathrm{C}_{12} \mathrm{H}_{11} \mathrm{IO}_{4}$ : C, 41.64; H, 3.20. Found: C, 41.48; H, 3.21.

\subsubsection{Octyl 5-hydroxy-6-iodo-2-methylbenzofuran-3-carboxylate (4)}

Octyl 5-hydroxy-2-methylbenzofuran-3-carboxylate (2) (12.16 g, $40 \mathrm{mmol}$ ) and iodine (24.38 g, $96 \mathrm{mmol}, 2.4$ equiv.) were dispersed in anhydrous methanol (60 mL) and stirred for 10 min. under argon. The mixture was cooled to $0^{\circ} \mathrm{C}$ and morpholine $(15.20 \mathrm{~mL}, 175 \mathrm{mmol}, 4.35$ equiv.) was added dropwise at a rate to keep the temperature below $30^{\circ} \mathrm{C}$, slowly heated to $35^{\circ} \mathrm{C}$, and stirred at this temperature for $48 \mathrm{~h}$. Water $(12 \mathrm{~mL})$ was added and the mixture was left at $-20^{\circ} \mathrm{C}$ overnight. Precipitate was filtered off, washed with cold methanol $\left(-25^{\circ} \mathrm{C}, 5 \times 25 \mathrm{~mL}\right)$ and dried to obtain 17.10 of beige solid. It was dispersed in chloroform $(300 \mathrm{~mL})$ and stirred for $5 \mathrm{~min}$. Insoluble precipitate of morpholine hydroiodide was filtered off and the filtrate was concentrated to obtain 
$10.02 \mathrm{~g}$ of crude brown product. Crystallization from methanol/water $(200 \mathrm{~mL} / 25 \mathrm{~mL})$ gave $8.89 \mathrm{~g}$ $(52 \%)$ of light yellow solid, $\mathrm{mp}=124-125^{\circ} \mathrm{C} .{ }^{1} \mathrm{H}$ NMR $\left(\mathrm{CDCl}_{3}, 700 \mathrm{MHz}\right) ; \delta \mathrm{ppm}: 0.90(\mathrm{t}, J=6.8 \mathrm{~Hz}$, $\left.3 \mathrm{H}, \mathrm{CH}_{3}\right), 1.26-1.42\left(\mathrm{~m}, 8 \mathrm{H}, 4 \mathrm{CH}_{2}\right), 1.44-1.51\left(\mathrm{~m}, 2 \mathrm{H}, \mathrm{CH}_{2}\right), 1.78-1.86\left(\mathrm{~m}, 2 \mathrm{H}, \mathrm{CH}_{2}\right), 2.75(\mathrm{~s}, 3 \mathrm{H}$, $\left.\mathrm{CH}_{3}\right), 4.36\left(\mathrm{t}, J=6.8 \mathrm{~Hz}, 2 \mathrm{H}, \mathrm{CH}_{2}\right), 5.44(\mathrm{~s}, 1 \mathrm{H}, \mathrm{OH}), 7.59\left(\mathrm{~s}, 1 \mathrm{H}, \mathrm{CH}_{\mathrm{Ar}}\right), 7.74\left(\mathrm{~s}, 1 \mathrm{H}, \mathrm{CH}_{\mathrm{Ar}}\right) .{ }^{13} \mathrm{C}$ NMR (DMSO-d 6 , $175 \mathrm{MHz}) ; \delta$ ppm: $14.01\left(\mathrm{CH}_{3}\right), 14.36\left(\mathrm{CH}_{3}\right), 22.14\left(\mathrm{CH}_{2}\right), 25.59\left(\mathrm{CH}_{2}\right), 28.23$ $\left(\mathrm{CH}_{2}\right), 28.67\left(\mathrm{CH}_{2}\right), 28.69\left(\mathrm{CH}_{2}\right), 31.23\left(\mathrm{CH}_{2}\right), 64.17\left(\mathrm{CH}_{2}\right), 80.95(\mathrm{C}), 105.15(\mathrm{CH}), 108.12(\mathrm{C})$, $120.34(\mathrm{CH}), 127.04(\mathrm{C}), 147.63(\mathrm{C}), 153.25$ (C), 163.38 (C), 164.22 (C). IR (ATR) $v_{\max } \mathrm{cm}^{-1}$ : $3266,2959,2918,2854,1669,1610,1580,1467,1448,1400,1355,1340,1262,1201,1184,1166$, 1152, 1099, 1021, 962, 887, 865, 840, 789, 726, 676, 661, 593, 558, 474. Anal. Calcd. for $\mathrm{C}_{18} \mathrm{H}_{23} \mathrm{IO}_{4}:$ C, 50.24; H, 5.39. Found: C, 50.53; H, 5.41.

2.2.5. Diethyl 6,6'-([2,2'-bipyridine $]-4,4^{\prime}$-diyl)bis(2-methylbenzo[1,2-b:4,5-b']difuran-3carboxylate) $(6 \boldsymbol{6})$

4,4'-Dibromo-2,2'-bipyridine (1.5699 g, $5 \mathrm{mmol}$ ), [1,1'-bis(diphenylphosphino)ferrocene]dichloropalladium(II) $(0.3660 \mathrm{~g}, 0.5 \mathrm{mmol}, 10 \% \mathrm{~mol})$, and copper iodide $(0.0952 \mathrm{~g}, 0.5 \mathrm{mmol}, 10 \%$ mol) were placed under argon in a Schlenk flask and dry toluene $(20 \mathrm{~mL})$ was added, followed by diisopropylamine $(10 \mathrm{~mL}, 70 \mathrm{mmol})$. The mixture was stirred for $15 \mathrm{~min}$. and ethynyltrimethylsilane $(1.2766 \mathrm{~g}, 13 \mathrm{mmol})$ in dry toluene $(5 \mathrm{~mL})$ was added in one portion. The mixture was heated to $80{ }^{\circ} \mathrm{C}$ until all ethynyltrimethylsilane was consumed, as judged by GC (1.5 h). It was cooled to $\mathrm{rt}$ and $1 \mathrm{M}$ tetrabutylammonium fluoride solution in THF (10 mL) was added. After 1 min. ethyl 5-hydroxy-6-iodo-2-methylbenzofuran-3-carboxylate $(3.4630 \mathrm{~g}, 10 \mathrm{mmol})$ in dry toluene $(50 \mathrm{~mL})$ was added and the mixture was heated to $80{ }^{\circ} \mathrm{C}$ for $20 \mathrm{~h}$. It was cooled to rt, water $(40 \mathrm{~mL})$ was added and filtered using Büchner funnel. Precipitate was returned to the flask, water $(50 \mathrm{~mL})$ and diethyl ether $(50 \mathrm{~mL})$ were added and stirred for $30 \mathrm{~min}$. The procedure was repeated using methanol $(120 \mathrm{~mL})$ and finally THF $(120 \mathrm{~mL})$. The precipitate was filtered using Büchner funnel and dried under vacuum to give $2.5070 \mathrm{~g}(78 \%)$ of pure desired product, $\mathrm{mp}>300{ }^{\circ} \mathrm{C} .1 \mathrm{H}$ NMR $\left(\mathrm{CDCl}_{3}, 700 \mathrm{MHz}\right) ; \delta$ ppm: $1.53\left(\mathrm{t}, J=7.1 \mathrm{~Hz}, 6 \mathrm{H}, 2 \times \mathrm{CH}_{3}\right), 2.82\left(\mathrm{~s}, 6 \mathrm{H}, 2 \times \mathrm{CH}_{3}\right), 4.48(\mathrm{q}$, 
$\left.J=7.1 \mathrm{~Hz}, 4 \mathrm{H}, 2 \times \mathrm{CH}_{2}\right), 7.47\left(\mathrm{~s}, 2 \mathrm{H}, 2 \times \mathrm{CH}_{\mathrm{Ar}}\right), 7.63\left(\mathrm{~s}, 2 \mathrm{H}, 2 \times \mathrm{CH}_{\mathrm{Ar}}\right), 7.81\left(\mathrm{~s}, 2 \mathrm{H}, 2 \times \mathrm{CH}_{\mathrm{Ar}}\right), 8.11(\mathrm{~s}$, $\left.2 \mathrm{H}, 2 \times \mathrm{CH}_{\mathrm{Ar}}\right), 8.83\left(\mathrm{~s}, 2 \mathrm{H}, 2 \times \mathrm{CH}_{\mathrm{Ar}}\right), 8.91\left(\mathrm{~s}, 2 \mathrm{H}, 2 \times \mathrm{CH}_{\mathrm{Ar}}\right)$. Solubility too low for ${ }^{13} \mathrm{C} \mathrm{NMR}$. IR (ATR) $v_{\max } \mathrm{cm}^{-1}: 2979,1709,1601,1368,1174,1157,1081,853,832,809,701$, 533. Anal. Calcd. for $\mathrm{C}_{38} \mathrm{H}_{28} \mathrm{~N}_{2} \mathrm{O}_{8}:$ C, 71.24; H, 4.41; N, 4.37. Found: C, 71.40; H, 4.38; N, 4.39.

2.2.6. Dioctyl 6,6'-([2,2'-bipyridine]-4,4'-diyl)bis(2-methylbenzo[1,2-b:4,5-b']difuran-3carboxylate) $(\boldsymbol{6} \boldsymbol{b})$

4,4'-Dibromo-2,2'-bipyridine (1.5699 g, $5 \mathrm{mmol}$ ), [1,1'-bis(diphenylphosphino)ferrocene]dichloropalladium(II) $(0.3660 \mathrm{~g}, 0.5 \mathrm{mmol}, 10 \% \mathrm{~mol})$, and copper iodide $(0.0952 \mathrm{~g}, 0.5 \mathrm{mmol}, 10 \%$ mol) were placed under argon in a Schlenk flask and dry toluene $(20 \mathrm{~mL})$ was added followed by diisopropylamine $(10 \mathrm{~mL}, \quad 70 \mathrm{mmol})$. The mixture was stirred for $15 \mathrm{~min}$. and ethynyltrimethylsilane $(1.2766 \mathrm{~g}, 13 \mathrm{mmol})$ in dry toluene $(5 \mathrm{~mL})$ was added in one portion. The mixture was heated to $80{ }^{\circ} \mathrm{C}$ until all ethynyltrimethylsilane was consumed as judged by $\mathrm{GC}(2 \mathrm{~h})$. It was cooled to rt and $1 \mathrm{M}$ tetrabutylammonium fluoride solution in THF $(13 \mathrm{~mL})$ was added. After 1 min. octyl 5-hydroxy-6-iodo-2-methylbenzofuran-3-carboxylate (4.3040 g, $10 \mathrm{mmol})$ in dry toluene $(50 \mathrm{~mL})$ was added and the mixture was heated to $80{ }^{\circ} \mathrm{C}$ for $14 \mathrm{~h}$. It was cooled to rt, water (40 mL) was added and filtered using Büchner funnel. Precipitate was returned to the flask, water $(50 \mathrm{~mL})$ and diethyl ether $(50 \mathrm{~mL})$ were added and stirred for $10 \mathrm{~min}$. The precipitate was filtered off and dried under vacuum, $3.8870 \mathrm{~g}(96 \%)$ of pure desired product, $\mathrm{mp}=212-214{ }^{\circ} \mathrm{C} .1 \mathrm{H} \mathrm{NMR}$ $\left(\mathrm{CDCl}_{3}, 700 \mathrm{MHz}\right) ; \delta \mathrm{ppm}: 0.89\left(\mathrm{t}, J=7.0 \mathrm{~Hz}, 6 \mathrm{H}, 2 \times \mathrm{CH}_{3}\right), 1.28-1.35\left(\mathrm{~m}, 8 \mathrm{H}, 4 \times \mathrm{CH}_{2}\right), 1.36-1.39$ (m, $\left.4 \mathrm{H}, 2 \times \mathrm{CH}_{2}\right), 1.41-1.45\left(\mathrm{~m}, 4 \mathrm{H}, 2 \times \mathrm{CH}_{2}\right), 1.51-1.55\left(\mathrm{~m}, 4 \mathrm{H}, 2 \times \mathrm{CH}_{2}\right), 1.87-1.91\left(\mathrm{~m}, 4 \mathrm{H}, 2 \times \mathrm{CH}_{2}\right)$, $2.82\left(\mathrm{~s}, 6 \mathrm{H}, 2 \times \mathrm{CH}_{3}\right), 4.41\left(\mathrm{t}, J=7.0 \mathrm{~Hz}, 4 \mathrm{H}, 2 \times \mathrm{CH}_{2}\right), 7.46\left(\mathrm{~s}, 2 \mathrm{H}, 2 \times \mathrm{CH}_{\mathrm{Ar}}\right), 7.62\left(\mathrm{~s}, 2 \mathrm{H}, 2 \times \mathrm{CH}_{\mathrm{Ar}}\right)$, $7.80\left(\mathrm{dd}, J=5.0 \mathrm{~Hz}, J=1.5 \mathrm{~Hz}, 2 \mathrm{H}, 2 \times \mathrm{CH}_{\mathrm{Ar}}\right), 8.10\left(\mathrm{~s}, 2 \mathrm{H}, 2 \times \mathrm{CH}_{\mathrm{Ar}}\right), 8.82\left(\mathrm{~d}, J=5.0 \mathrm{~Hz}, 2 \mathrm{H}, 2 \times \mathrm{CH}_{\mathrm{Ar}}\right)$, $8.90\left(\mathrm{~s}, 2 \mathrm{H}, 2 \times \mathrm{CH}_{\mathrm{Ar}}\right)$. Solubility too low for ${ }^{13} \mathrm{C}$ NMR. IR (ATR) $v_{\max } \mathrm{cm}^{-1}: 2928,2861,1708$, $1605,1592,1406,1383,1368,1239,1222,1176,1151,1117,1091,1043,988,923,863,832,808$, 796, 701. Anal. Calcd. for $\mathrm{C}_{50} \mathrm{H}_{52} \mathrm{~N}_{2} \mathrm{O}_{8}$ : C, 74.24; H, 6.48; N, 3.46. Found: C, 74.43; H, 6.50; N, 3.49 . 


\subsection{7. (TBA $\left(R u\left[(4-\right.\right.$ carboxylic acid-4'-carboxylate-2,2'-bipyridine $)($ Ligand-6a $\left.\left.\left.)(N C S)_{2}\right]\right)\right)$}

(M44)

A mixture of dichloro( $p$-cymene)ruthenium(II) dimer $(0.3062 \mathrm{~g}, 0.5 \mathrm{mmol})$ and $\mathbf{6 a}(0,6402$ $\mathrm{g}, 1 \mathrm{mmol})$ in dry DMF (40 mL) was stirred in the dark, under argon at $150^{\circ} \mathrm{C}$, monitoring the disappearance of substrates and appearance of product by UV-Vis spectrometry $(\sim 2 \mathrm{~h}) .2,2^{\prime}-$ Bipyridine-4,4'-dicarboxylic acid $(0.2442 \mathrm{~g}, 1 \mathrm{mmol})$ was added and the mixture was stirred at $150^{\circ} \mathrm{C}$ for $4 \mathrm{~h}$. Ammonium thiocyanate $(2.74 \mathrm{~g}, 36.5 \mathrm{mmol})$ was added and the mixture was stirred at $150^{\circ} \mathrm{C}$ for another $4 \mathrm{~h}$. It was cooled to rt, filtered, and DMF was removed with the rotary evaporator. To the residual slurry water $(100 \mathrm{~mL})$ was added and filtered. Precipitate was washed with water $(100 \mathrm{~mL})$ and dried under vacuum. The crude product was dissolved in DMF and then passed through a Sephadex LH-20 column with DMF as eluent. The main band was collected and concentrated. This purification process was repeated three times. Pure complex was dispersed in ethanol and titrated with $0.5 \mathrm{M}$ tetrabutylammonium hydroxide solution to $\mathrm{pH}=9$, stirred for 5 min., filtered, and the filtrate was titrated with $0.01 \mathrm{M} \mathrm{HNO}_{3}$ to $\mathrm{pH}=5.2$. Solvents were removed with the rotary evaporator, the product was washed with acidified water $(\mathrm{pH}=5.2)$, and dried under vacuum and $\mathrm{P}_{2} \mathrm{O}_{5}$ to obtain $0.4966 \mathrm{~g}(36 \%)$ of pure complex as black plates, mp $>300^{\circ} \mathrm{C}$. IR-ATR, $\mathrm{cm}^{-1}$ : $2962,2935,2856,2100,1707,1611,1467,1426,1402,1362,1305,1235,1176,1083,1019,979$, 921, 853, 807, 782, 705, 473. Anal. Calcd. for $\mathrm{C}_{52} \mathrm{H}_{35} \mathrm{~N}_{6} \mathrm{O}_{12} \mathrm{RuS}_{2} \cdot \mathrm{TBA} \cdot 2 \mathrm{H}_{2} \mathrm{O}: \mathrm{C}, 59.20 ; \mathrm{H}, 5.48$; N, 7.11. Found: C, 59.41; H, 5.52; N, 7.16.

2.2.8. $\left(\operatorname{TBA}\left(\mathrm{Ru}\left[(4\right.\right.\right.$-carboxylic $\quad$ acid-4'-carboxylate-2,2'-bipyridine $)($ Ligand-6b $\left.\left.\left.)(N C S)_{2}\right]\right)\right)$ (M43)

A mixture of dichloro(p-cymene)ruthenium(II) dimer $(0.3062 \mathrm{~g}, 0.5 \mathrm{mmol})$ and $\mathbf{6 a}(0,809 \mathrm{~g}$, $1 \mathrm{mmol})$ in dry DMF (40 mL) was stirred in the dark, under argon at $150^{\circ} \mathrm{C}$, monitoring the disappearance of substrates and appearance of product by UV-Vis spectrometry $(\sim 2 \mathrm{~h}) .2,2^{\prime}-$ Bipyridine-4,4'-dicarboxylic acid $(0.2442 \mathrm{~g}, 1 \mathrm{mmol})$ was added and the mixture was stirred at 
$150^{\circ} \mathrm{C}$ for $4 \mathrm{~h}$. Ammonium thiocyanate $(2.74 \mathrm{~g}, 36.5 \mathrm{mmol})$ was added and the mixture was stirred at $150^{\circ} \mathrm{C}$ for another $4 \mathrm{~h}$. It was cooled to rt, filtered, and DMF was removed with the rotary evaporator. To the residual slurry water $(100 \mathrm{~mL})$ was added and filtered. Precipitate was washed with water $(100 \mathrm{~mL})$ and dried under vacuum. The crude product was dissolved in DMF and then passed through a Sephadex LH-20 column with DMF as eluent. The main band was collected and concentrated. This purification was repeated three times. Pure complex was dispersed in ethanol and titrated with $0.5 \mathrm{M}$ tetrabutylammonium hydroxide solution to $\mathrm{pH}=9$. It was stirred for $5 \mathrm{~min}$., filtered and the filtrate was titrated with $0.01 \mathrm{M} \mathrm{HNO}_{3}$ to $\mathrm{pH}=5.2$. Solvents were removed with the rotary evaporator, the product was washed with acidified water $(\mathrm{pH}=5.2)$, and dried under vacuum and $\mathrm{P}_{2} \mathrm{O}_{5}$ to obtain $0.5418 \mathrm{~g}(35 \%)$ of black plates, $\mathrm{mp}>300^{\circ} \mathrm{C}$. IR-ATR, $\mathrm{cm}-1: 2962,2935,2856$, $2100,1707,1611,1467,1426,1402,1362,1305,1235,1176,1083,1019,979,921,853,807,782$, 705, 473. Anal. Calcd. for $\mathrm{C}_{64} \mathrm{H}_{59} \mathrm{~N}_{6} \mathrm{O}_{12} \mathrm{RuS}_{2} \cdot \mathrm{TBA} \cdot 2 \mathrm{H}_{2} \mathrm{O}$ : C, 62.08; H, 6.45; N, 6.33. Found: C, 61.98; H, 6.42; N, 6.37.

The NMR spectra of the dyes are complex because they contain mixture of two diastereoisomers. As a result, the NMR spectra exhibit groups of broad peaks in the 6-9 ppm region that cannot be separated and unambiguously assigned, and have not been described.

\subsection{Device fabrication}

Fluorine-doped $\mathrm{SnO}_{2}$ (FTO) glass plates (AGC ANS10ME, thickness $3.2 \mathrm{~mm}, 10 \Omega / \mathrm{sq}$ ) with dimensions $200 \times 70 \mathrm{~mm}$ were structured by means of ytterbium laser in order to obtain eight separated areas on photoanode and counter electrode. Then two holes $(\varnothing 1 \mathrm{~mm})$ were drilled in counter electrode. After that glass plates were washed in ultrasonic bath containing de-ionized water, acetone and ethanol. A transparent single layer of $20-\mathrm{nm}$ sized $\mathrm{TiO}_{2}$ particles (18NR-T, Dyesol) and silver stripes (AG 7500-80, Johnson Matthey) were screen-printed on photoanode. A nanocolloidal Pt (3D-nano) layer and silver stripes were applied on counter electrode in the same way. All layers thickness was precisely determined using optical profiler (Sensofar PLU Neox), and 
the fabricated $\mathrm{TiO}_{2}$ film thickness was around $5 \mu \mathrm{m}$ (Fig. 1). Finally, the plates were dried at $150^{\circ} \mathrm{C}$ for $30 \mathrm{~min}$. and annealed at $480^{\circ} \mathrm{C}$ for $45 \mathrm{~min}$. Dyeing process was conducted using dip dyeing and flow dyeing methods. In dip dyeing process photoanodes were immersed in solutions containing $1 \times 10^{-4} \mathrm{M}$ dyes $(\mathbf{M 4 3}, \mathbf{M 4 4}, \mathbf{N 7 1 9}, \mathbf{Z 9 0 7})$ in ethanol for 24 hours at room temperature. After dyeing the plates were rinsed with pure ethanol and dried under nitrogen. The dye-coated $\mathrm{TiO}_{2}$ electrodes and Pt counter electrodes were assembled into a sealed sandwich-type cell by heating with a hotmelt ionomer film (Surlyn 1702, $25 \mu$ m thickness, DuPont) as a spacer between the electrodes. An encapsulation process was performed at $110^{\circ} \mathrm{C}$. The cell internal space was filled with a liquid electrolyte (EL-HPE, Dyesol) using the holes on the counter electrode, which were sealed by heating with a Surlyn sheet and a thin glass cover. The flow dyeing procedure was conducted after electrodes encapsulation. The same dyes solutions were flown through the cell for 8 hours using peristaltic pomp and electrolyte-injecting holes. The obtained DSSC devices consists of eight 8 individual cells (Fig. 2), active area of single cell was $5 \mathrm{~cm}^{2}$. In order to assure reliable results, six DSSC devices for each dye were prepared, where three of them were used in dip dyeing and next three in flow dyeing method.
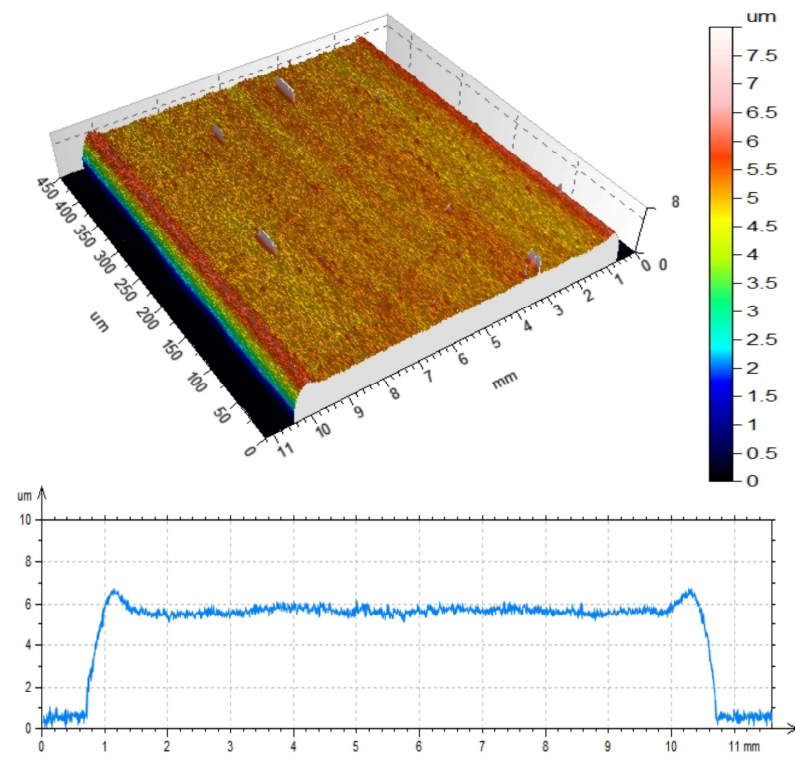

Fig. 1. Topography and profile of nanocrystalline $\mathrm{TiO}_{2}$ layer deposited on photoelectrode 


\subsection{Photovoltaic measurements}

The DSSC devices were evaluated under $100 \mathrm{~mW} / \mathrm{cm}^{2}$ standard air mass 1.5 global (AM 1.5G) sunlight simulation with a class AAA solar cell analyzer (Model No. \#SS150AAA, PV Test Solutions) conjugated with Keithley model 2401 digital source meter. A silicon solar cell fitted with a KG3 filter tested and certified by Fraunhofer ISE was used for calibration. The KG3 filter accounts for the different light absorption of the dye-sensitized solar cell and silicon, and ensues that the spectral mismatch correction factor approaches unity. The voltage step and scan rate were $10 \mathrm{mV}$ and $100 \mathrm{~ms}$, respectively. A special black plastic mask with an aperture area of $5 \mathrm{~cm}^{2}$ was covered on each testing cell during measurement to eliminate light reflection leading to unreliable results. Incident photo-current efficiency (IPCE) studies were carried out by means of Bentham PVE 300 analyzer, with xenon/quartz halogen light source and measured in DC mode with low chopping frequency $(<1 \mathrm{~Hz})$. The device was calibrated with reference photodiode DH Si. A cell spectral response was obtained at $25^{\circ} \mathrm{C}$ for wavelengths range $300-800 \mathrm{~nm}$ with $5 \mathrm{~nm}$ step. 


\section{Results and discussion}

\subsection{Synthesis}

The aim of this work was the development and photovoltaic characterization of new heteroleptic ruthenium complexes for DSSC application, containing BDF moiety combined with 2,2'-bipyridine as ligands and their comparison with commercially available N719 and Z907 dyes (Fig. 3). The heteroleptic complexes were prepared using ester form of BDF ligands and 2,2'bipyridine-4,4'-dicarboxylic acid. Two alkyl esters, ethyl and 1-octyl, have been chosen to investigate the effect of the ester chain length on the solubility of dyes and efficiency of fabricated dye-sensitized solar cells based on these dyes.

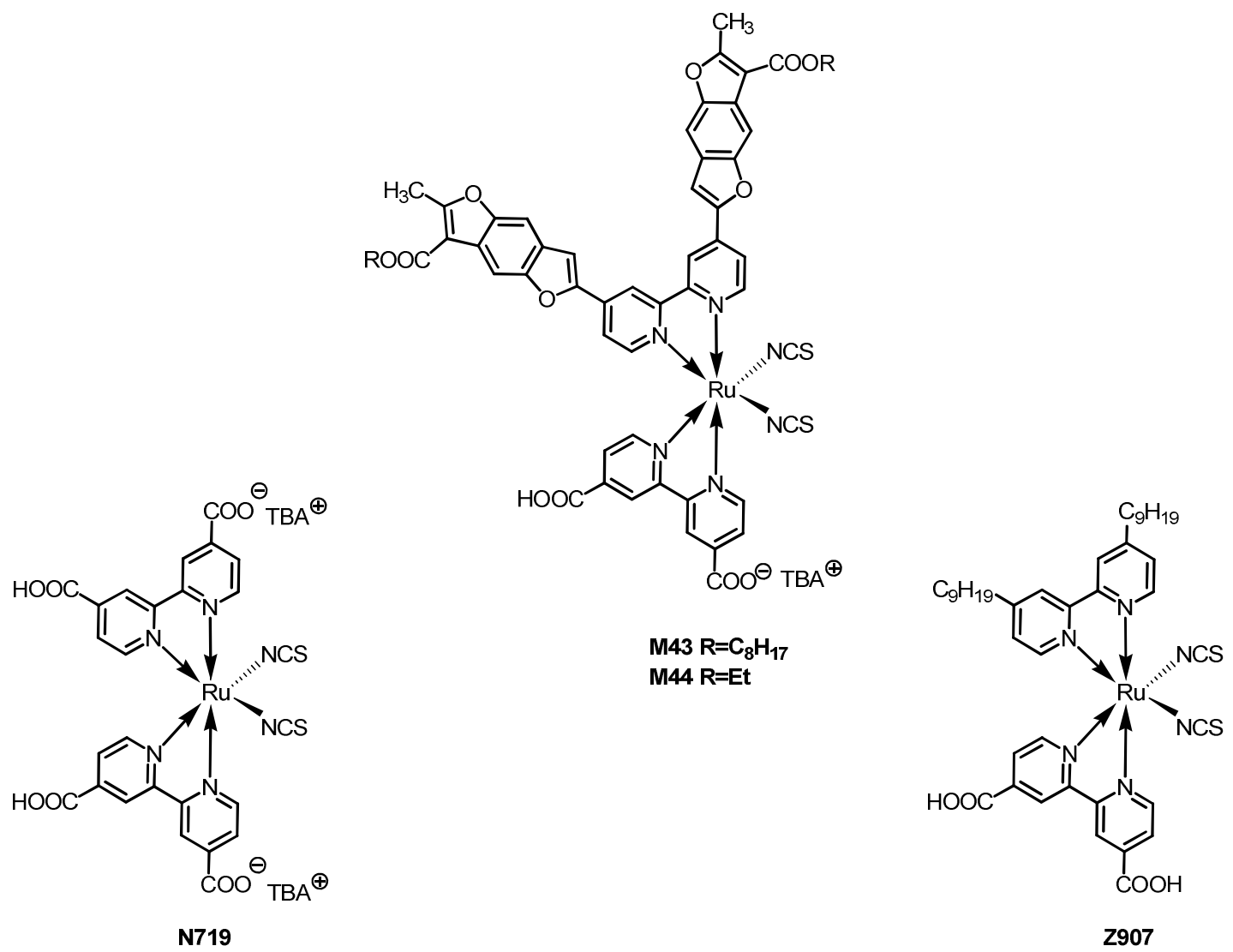

Fig. 3. Molecular structures of N719, Z907, M43 and M44 
The synthesis of BDF ligands started from ethyl and n-octyl 5-hydroxy-6-iodo-2methylbenzofuran-3-carboxylates $(\mathbf{3}, \mathbf{4})$ obtained as shown in Scheme 1. Ethyl 5-hydroxy-2methylbenzofuran-3-carboxylate (1) was prepared according to Bernatek and Ledaal [28] procedure from $p$-benzoquinone and ethyl acetylacetate in the presence of anhydrous zinc chloride in $43 \%$ yield. Acid catalyzed transesterification with 1-octanol led to octyl 5-hydroxy-2-methylbenzofuran3-carboxylate (2) in $80 \%$ yield. Both $\mathbf{1}$ and $\mathbf{2}$ were iodinated by modified Giza and Hinman [27] protocol to give the desired products 3 and 4 in 34\% and 52\% yield respectively.
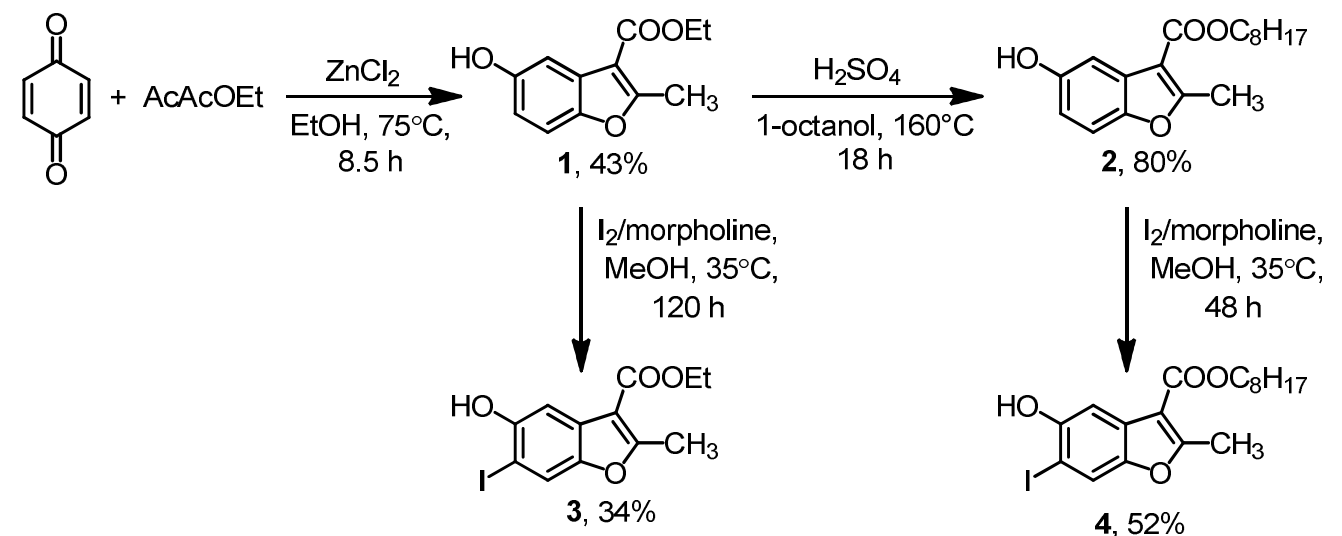

Scheme 1. Synthesis of 5-hydroxy-6-iodo-2-methylbenzofuran-3-carboxylates for the Sonogashira coupling.

The BDF ligands $\mathbf{6 a}$ and $\mathbf{6 b}$ were prepared in the one-pot procedure involving the Sonogashira coupling reaction and palladium catalyzed cyclization leading to a new furan ring (Scheme 2). 4,4'-Dibromo-2,2'-bipyridine reaction with ethynyltrimethylsilane in the presence of $10 \%$ mol [1,1'-bis(diphenylphosphino)ferrocene]dichloropalladium(II) and copper iodide in toluene followed by cleavage of trimethylsilyl groups with tetrabutylammonium fluoride led to 4,4'diethynyl-2,2'-bipyridine (5). 

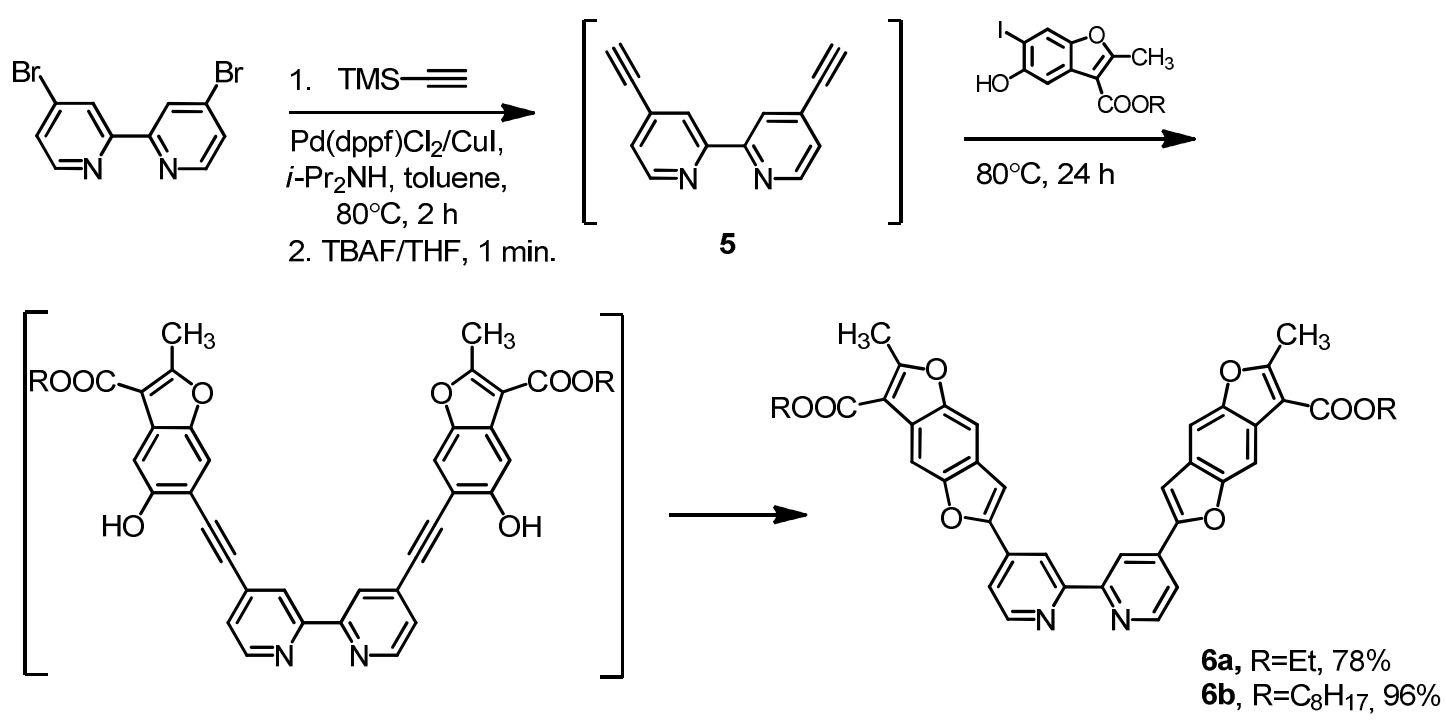

Scheme 2. The "one pot" synthesis of BDF-bipyridine ligands.

Addition of $\mathbf{3}$ or $\mathbf{4}$ to the reaction flask resulted in the second Sonogashira reaction followed by palladium catalyzed cyclization of hydroxyl group and triple bond to form a new furan ring in $78 \%$ and $96 \%$ yield, respectively. Unfortunately all attempts to hydrolyze the ester groups failed, mainly due to low solubility of both esters and acid in polar solvents.

The desired heteroleptic ruthenium complexes were prepared in one-pot process (Scheme 3). The BDF ligands were reacted with dichloro( $p$-cymene)ruthenium(II) dimer until all substrates were consumed, as judged by UV-Vis spectra $(\sim 2 \mathrm{~h})$. The resulting intermediate complexes were reacted with 2,2'-bipirydylo-4,4'-dicarboxylic acid and then with ammonium thiocyanate to replace chlorine atoms with isothiocyanate groups.
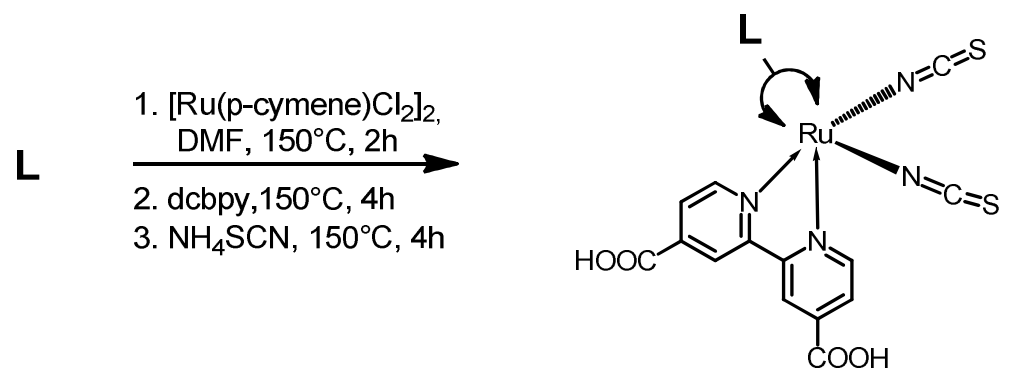

M43, L=6b, 35\%

M44, L=6a, 36\%

Scheme 3. Synthesis of heteroleptic BDF-bipyridine-dcbpy ruthenium(II) complexes 
The reaction proceeds similarly when ruthenium(III) chloride is used as a source of ruthenium. Crude products were purified by column chromatography on Sephadex LH-20 with DMF as eluent. The main band was collected, and the process was repeated three times. Pure complexes were titrated in ethanol with tetrabutylammonium hydroxide solution to $\mathrm{pH}=9$ and then with $0.01 \mathrm{M} \mathrm{HNO}_{3}$ to $\mathrm{pH}=5.2$. The complexes (dyes) were obtained as black, shiny microcrystalline solids.

\subsection{Spectroscopic properties of the dyes}

The dyes M43 and M44 showed good solubility in ethanol and $1 \times 10^{-4} \mathrm{M}$ solutions, required for dyeing process, were prepared. Their UV-Vis spectra in comparison with commercial N719 and Z907 (Fig. 4) were recorded at lower concentration $\left(5 \times 10^{-6} \mathrm{M}\right)$ to achieve absorbance below 0.1 for low-energy CT band at $\sim 530 \mathrm{~nm}$ and to avoid deviations from the Beer-Lambert law. The visible region band is typical for heteroleptic polypyridyl ruthenium(II) complexes [13,29].

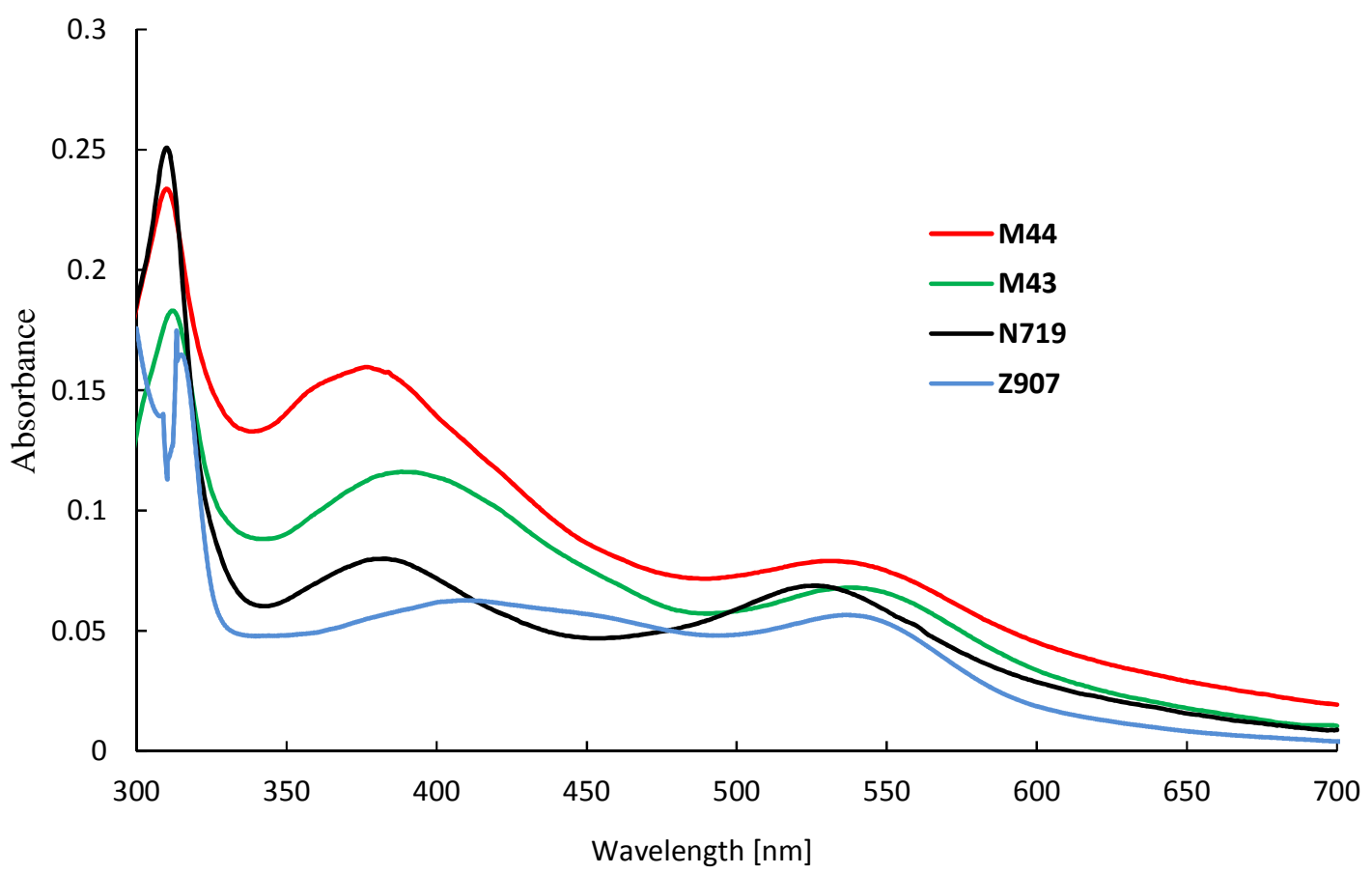

Fig. 4. Absorption spectra of M43, M44, N719, and Z907 in ethanol 
The spectra revealed higher molar extinction coefficient of M43 and M44 for both LCCT (350-450 nm) and MLCT (500-600 nm) absorption bands in comparison to commercial dyes (Fig. 4). Although the low energy MLCT band for M43 has almost the same molar absorption coefficient as $\mathbf{N 1 9}\left(\varepsilon=13600 \mathrm{M}^{-1} \mathrm{~cm}^{-1}\right.$ vs. $\left.\varepsilon=13760 \mathrm{M}^{-1} \mathrm{~cm}^{-1}\right)$ the molar absorption coefficient for LCCT band is much higher $\left(\varepsilon=23200 \mathrm{M}^{-1} \mathrm{~cm}^{-1}\right.$ vs. $\left.\varepsilon=16000 \mathrm{M}^{-1} \mathrm{~cm}^{-1}\right)$ (Table 1$)$.

Table 1. Molar absorption coefficients and wavelengths maxima for M43, M44, N719, and Z907 in ethanol

\begin{tabular}{ccc}
\hline Dye & LCCT $\varepsilon\left[\mathrm{M}^{-1} \mathrm{~cm}^{-1}\right] / \lambda_{\max }[\mathrm{nm}]$ & MLCT $\varepsilon\left[\mathrm{M}^{-1} \mathrm{~cm}^{-1}\right] / \lambda_{\max }[\mathrm{nm}]$ \\
\hline M43 & $23200 / 391$ & $13600 / 538$ \\
M44 & $31940 / 377$ & $15800 / 533$ \\
$\mathbf{N 7 1 9}$ & $16000 / 382$ & $13760 / 526$ \\
$\mathbf{Z 9 0 7}$ & $12534 / 411$ & $6440 / 521$
\end{tabular}

The M44 dye revealed even higher molar absorption coefficient for both LCCT and MLCT bands than M43. The MLCT transition absorption for M43 and M44 peaks at $538 \mathrm{~nm}$ and $533 \mathrm{~nm}$, respectively, are red-shifted compared to Z907 (521 nm) and N719 (526 nm). 


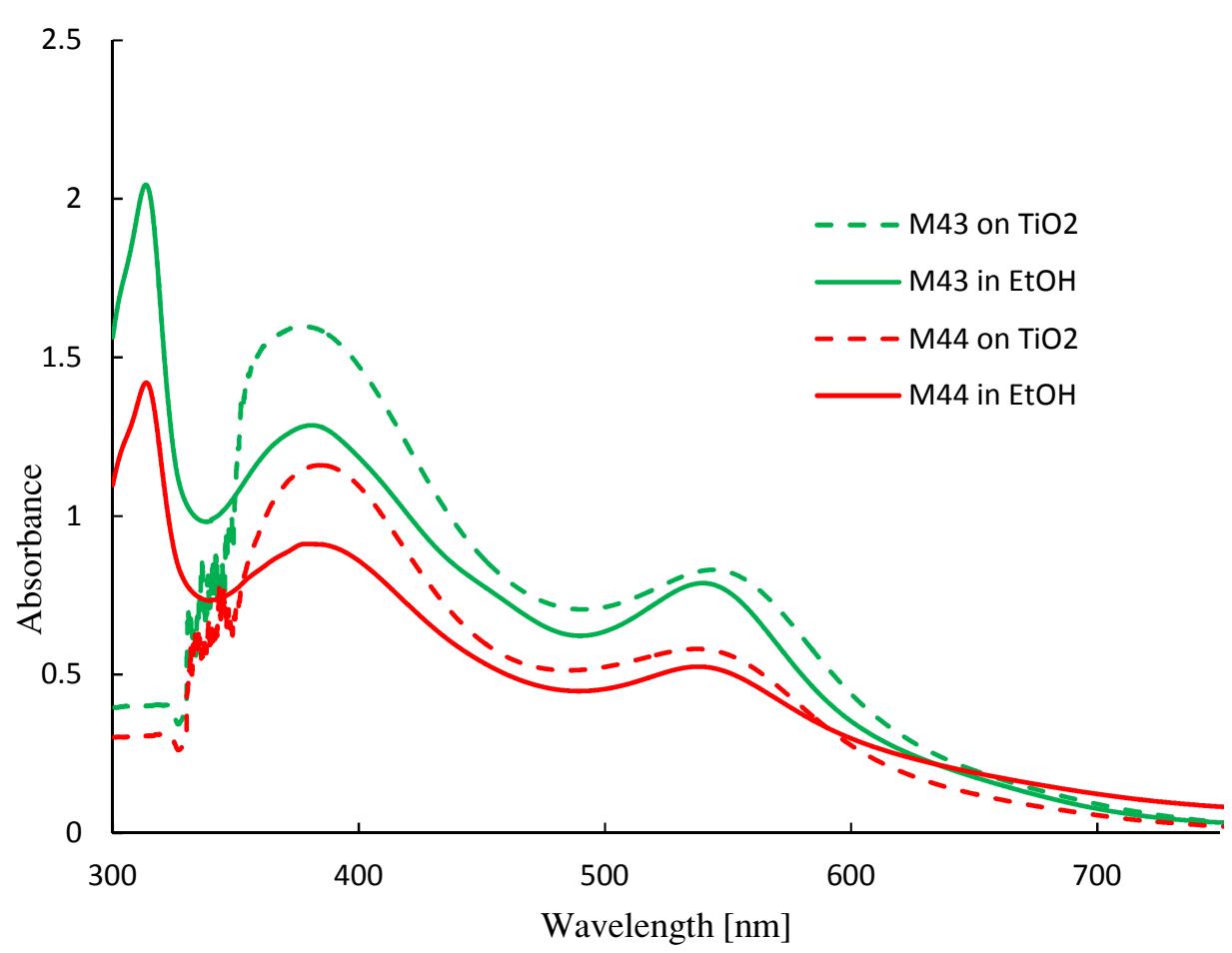

Fig. 5. Absorption spectra of M43 and M44 in ethanol and anchored on a $5 \mu \mathrm{m}$ thick transparent nanocrystalline $\mathrm{TiO}_{2}$ film.

The spectra of M43 and M44 solutions in ethanol, and anchored on a $5 \mu \mathrm{m}$ thick transparent nanocrystalline $\mathrm{TiO}_{2}$ film, have almost identical profiles (Fig. 5).

\subsection{Photovoltaic characterization}

Two methods of dyeing test cells coated with a thin layer $(5 \mu \mathrm{m})$ of titanium dioxide were examined - dip dyeing and flow dyeing. DSSC photovoltaic performances were used in order to compare these methods and applied dyes. For each cell, photovoltaic parameters such as: opencircuit voltage $\left(\mathrm{V}_{\mathrm{oc}}\right)$, short-circuit current $\left(\mathrm{I}_{\mathrm{sc}}\right)$, fill factor $(\mathrm{FF})$, max power output $\left(\mathrm{P}_{\mathrm{m}}\right)$, max power voltage $\left(V_{m}\right)$, max power current $\left(I_{m}\right)$, and solar-to-electric energy conversion efficiency $(\eta)$ were determined. For each applied dye 48 cells were measured: 24 for dip dyeing and 24 for flow dyeing method. The obtained average results were summarized in Table 2. Moreover, Fig. 6 and Fig. 7 present current-voltage characteristics and spectral response as a function of wavelength for chosen cells, respectively. 
Table 2. Average photovoltaic parameters of the dye-sensitized solar cells with different sensitizers for two dyeing methods

\begin{tabular}{cccccccc}
\hline \multicolumn{7}{c}{ Dip dyeing } \\
\hline Complex & $\mathrm{V}_{\mathrm{oc}}[\mathrm{mV}]$ & $\mathrm{I}_{\mathrm{sc}}[\mathrm{mA}]$ & $\mathrm{V}_{\mathrm{m}}[\mathrm{mV}]$ & $\mathrm{I}_{\mathrm{m}}[\mathrm{mA}]$ & $\mathrm{P}_{\mathrm{m}}[\mathrm{mW}]$ & $\mathrm{FF}$ & $\eta[\%]$ \\
M43 & 664 & 29.2 & 479 & 26.5 & 12.7 & 0.66 & 2.54 \\
$\mathbf{M 4 4}$ & 666 & 29.7 & 479 & 26.4 & 12.8 & 0.65 & 2.56 \\
$\mathbf{N 7 1 9}$ & 679 & 24.2 & 511 & 22.2 & 11.3 & 0.69 & 2.26 \\
$\mathbf{Z n 9 0 7}$ & 742 & 19.1 & 529 & 17.0 & 8.91 & 0.64 & 1.75 \\
\hline
\end{tabular}

Flow dyeing

\begin{tabular}{cccccccc}
\hline Complex & $\mathrm{V}_{\mathrm{oc}}[\mathrm{mV}]$ & $\mathrm{I}_{\mathrm{sc}}[\mathrm{mA}]$ & $\mathrm{V}_{\mathrm{m}}[\mathrm{mV}]$ & $\mathrm{I}_{\mathrm{m}}[\mathrm{mA}]$ & $\mathrm{P}_{\mathrm{m}}[\mathrm{mW}]$ & $\mathrm{FF}$ & $\eta[\%]$ \\
$\mathbf{M 4 3}$ & 662 & 28.8 & 479 & 26.2 & 12.5 & 0.66 & 2.51 \\
$\mathbf{M 4 4}$ & 670 & 32.7 & 473 & 29.7 & 14.0 & 0.64 & 2.81 \\
$\mathbf{N 7 1 9}$ & 671 & 25.5 & 495 & 23.5 & 11.6 & 0.68 & 2.32 \\
$\mathbf{Z 9 0 7}$ & 764 & 21.2 & 550 & 19.0 & 10.5 & 0.65 & 2.06 \\
\hline
\end{tabular}




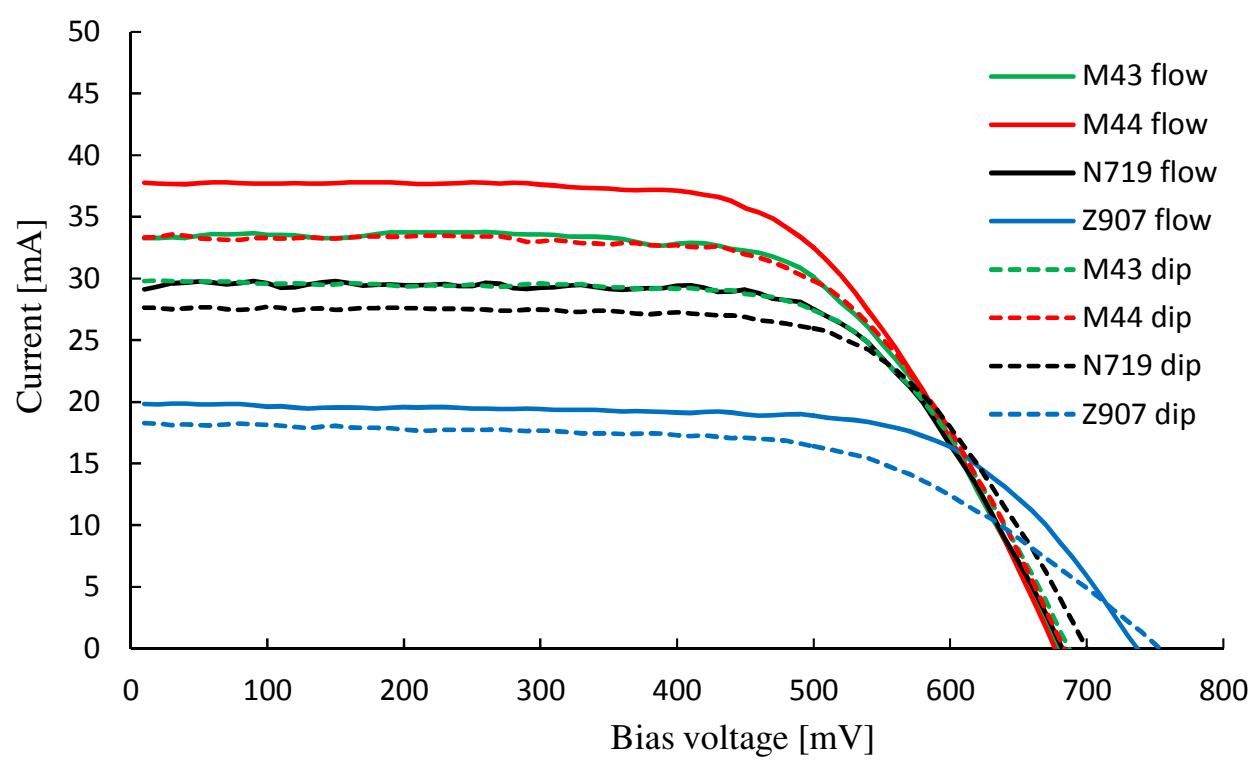

Fig. 6. Current - voltage characteristics of DSSC with M43, M44, N719 and Z907 sensitizers for two dyeing methods measured under illumination of AM1.5G sunlight $\left(100 \mathrm{~mW} / \mathrm{cm}^{2}\right)$. Aperture area of the testing mask: $5 \mathrm{~cm}^{2}$

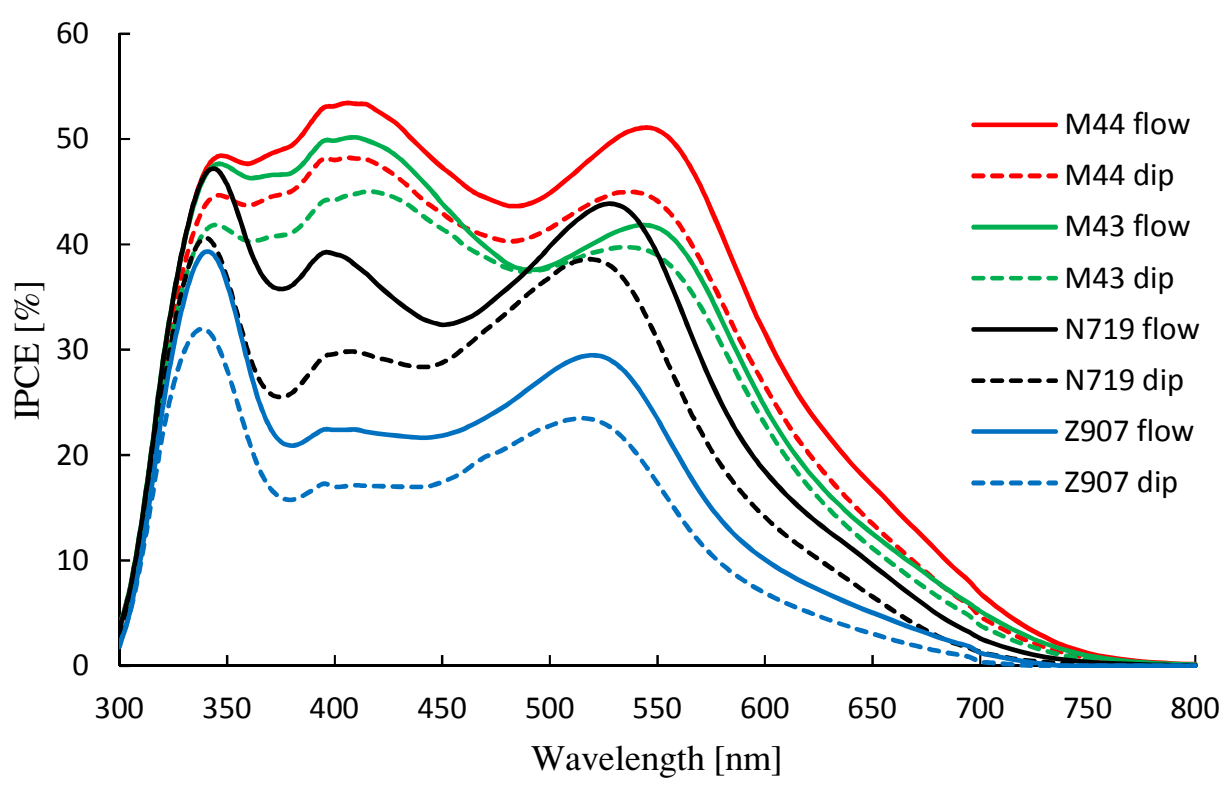

Fig. 7. Incident-photon-to-current conversion efficiency spectra of DSSC based on nanocrystalline $\mathrm{TiO}_{2}$ film sensitized by M43, M44, N719 and Z907 dyes for two dyeing methods 
As shown in Table 2, the short-circuit current $\left(\mathrm{I}_{\mathrm{sc}}\right)$ of cells with newly synthetized M44 and M43 dyes is higher than with commercially available N719 and Z907 sensitizers, what corresponds to their higher efficiency and power. This tendency is visible for both dyeing methods. However, a significant difference between these methods was noticed. Thus, considering the same photovoltaic parameters, the obtained values for the dip dyeing are lower than for the flow dyeing process, e.g. the cell with $\mathrm{M} 44$ dye exhibits an increase in $\mathrm{I}_{\mathrm{sc}}$ and in $\eta$ from $29.7 \mathrm{~mA}$ to $32.7 \mathrm{~mA}$ and $2.56 \%$ to $2.81 \%$, respectively. This trend is also observed in incident photon-to-current efficiency (IPCE) plots. IPCE indicates the ratio of the number of photons incident on a solar cell to the number of generated charge carriers. The obtained results for devices with newly synthesized dyes show higher IPCE values in the wavelength range of 350-490 nm and 540-700 $\mathrm{nm}$ in comparison to N719 and Z907 dyes (Fig. 7). However, N719 has slightly better performance than M43 above $490 \mathrm{~nm}$ up to $540 \mathrm{~nm}$, but worse than M44. The M44 sensitizer has an advantage over the other studied dyes and achieves the highest IPCE values in the entire wavelength range. It was noticed that photovoltaic parameters strongly depend on the dyes absorption properties. Having compared Fig. 4 and Fig. 7 a good relationship was observed between behavior of the dyes in solution and in working DSSC device. The investigated dyes indicate the highest absorption in the spectral region from 350 to $560 \mathrm{~nm}$ which is correlated with the achieved IPCE values. To sum up, the evaluated DSSCs, based on nanocrystalline $\mathrm{TiO}_{2}$ film sensitized by M43, M44, N719 and Z907 dyes for two dyeing methods, exhibit the same trend with the order M44 $>$ M43 $>$ N719 $>$ Z907 for currentvoltage characteristics and IPCE curves. However, the flowing process gives better photovoltaic parameters than the dipping process.

Moreover, the flow dyeing method has further advantages in comparison to dip dyeing process from practical point of view. Firstly, it does not need as much dye solution as the second method. Secondly, flow dyeing time is shorter than dip dyeing and takes only $8 \mathrm{~h}$ whereas dipping needs $24 \mathrm{~h}$. Additionally, flow dyeing process is carried out in a closed system, without contact with moisturizing air, which may cause dyes degradation. 
Its noteworthy that values of efficiency for cells sensitized by commercially available dyes are 4 times smaller than reported in literature. This can be explained by the fact that we applied testing conditions more similar to the industrial ones. There was used much larger testing cell area $\left(5 \mathrm{~cm}^{2}\right)$ than $0.158 \mathrm{~cm}^{2}$ standard testing cell reported in the literature, and only single $5 \mu \mathrm{m}$ transparent layer without scattering layer was used to maintain maximum transparency. The "green" solvent, ethanol, preferred in industrial applications was used. In these conditions our heteroleptic dyes revealed much higher efficiency than the most commonly used heteroleptic dye Z907 (145\% and $146 \%$ for M43 and M44, respectively using dip dyeing, and 121\% and 136\%, respectively using flow dyeing process). Moreover, both newly synthesized dyes revealed also higher efficiency than the most commonly used homoleptic dye N719 (112\% and $113 \%$ for M43 and M44, respectively using dip dyeing, and $108 \%$ and $121 \%$, respectively using flow dyeing process). Assuming that the efficiency of $0.158 \mathrm{~cm}^{2}$ standard testing cell sensitized with $\mathbf{N 7 1 9}$ in laboratory conditions is $11.18 \%{ }^{6}$ using dip dyeing in $1: 1$ mixture of acetonitrile:tert-butanol, $\mathrm{c}=5 \times 10^{-4} \mathrm{M}$, we predict that M43 and M44 could achieve in these conditions efficiency of $\sim 12.6 \%$.

\section{Conclusion}

We report herein the design, synthesis, and characterization of novel heteroleptic ruthenium dyes M43 and M44 containing benzodifuran moieties conjugated with the anchoring 2,2'-bipyridine group as a ligand. Both newly synthesized dyes revealed increased molar extinction coefficients compared with Z907 and N719 dyes in the visible light and the near-IR regions. Two dyeing methods, dip and flow dyeing, were used for the preparation of large area testing cells. The evaluated DSSCs based on nanocrystalline $\mathrm{TiO}_{2} 5 \mu \mathrm{m}$ transparent film, sensitized by M43, M44, N719 and Z907 dyes for two dyeing methods, exhibit the same trend with the order M44 $>$ M43 $>$ N719 $>$ Z907 for current-voltage characteristics and IPCE curves, however, cells prepared in the flowing process revealed better photovoltaic parameters than prepared in dipping. The newly synthesized dyes revealed higher energy conversion efficiency $(\eta)$, measured at the AM1.5G conditions, up to $21 \%$ compared to $\mathbf{N 7 1 9}$ and up to $46 \%$ compared to Z907. 


\section{Acknowledgments}

We acknowledge financial support of this work by The National Centre for Research and Development, Warsaw, POIG.01.04.00-04-097/12 and POIG.01.04.00-18-101/12 Grants.

\section{References}

1. O'Regan B, Grätzel M. A low-cost, high-efficiency solar cell based on dye-sensitized colloidal TiO2 films. Nature 1991;353:737-40.

2. http://www.nrel.gov/ncpv/images/efficiency_chart.jpg

3. Zhou H, Chen Q, Li G, Luo S, Song TB, Duan HS, et al. Interface engineering of highly efficient perovskite solar cells. Science 2014;345:542-6.

4. Nazeeruddin MK, Kay A, Rodicio I, Humpbry-Baker R, Müller E, Liska P, et al. Conversion of light to electricity by cis-X2bis(2,2'-bipyridyl-4,4'-dicarboxylate)ruthenium(II) charge-transfer sensitizers ( $\mathrm{X}=\mathrm{Cl}-, \mathrm{Br}-, \mathrm{I}-, \mathrm{CN}-$, and $\mathrm{SCN}-)$ on nanocrystalline titanium dioxide electrodes. J Am Chem Soc 1993;115:6382-90.

5. Nazeeruddin MK, Zakeeruddin SM, Humphry-Baker R, Jirousek M, Liska P, Vlachopoulos N, et al. Acid-base equilibria of (2,2‘-bipyridyl-4,4`-dicarboxylic acid)ruthenium(II) complexes and the effect of protonation on charge-transfer sensitization of nanocrystalline titania. Inorg Chem 1999;38:6298-305.

6. Nazeeruddin MK, De Angelis F, Fantacci S, Selloni A, Viscardi G, Liska P, et al. J Am Chem Soc $2005 ; 127: 16835-47$.

7. Wang Q, Ito S, Gra $\square$ tzel M, Fabregat-Santiago F, Mora-Seró I, Bisquert J, et al. Characteristics of high efficiency dye-sensitized solar cells. J Phys Chem B 2006;110:25210-21.

8. Wang P, Zakeeruddin SM, Moser JE, Nazeeruddin MK, Sekiguchi T, Gra $\square$ tzel M. A stable quasi-solid-state dye-sensitized solar cell with an amphiphilic ruthenium sensitizer and polymer gel electrolyte. Nat Mater 2003;2:402-7. 
9. Wang P, Zakeeruddin SM, Comte P, Charvet R, Humphry-Baker R, Gra $\square$ tzel M. Enhance the performance of dye-sensitized solar cells by co-grafting amphiphilic sensitizer and hexadecylmalonic acid on $\mathrm{TiO}_{2}$ nanocrystals. J Phys Chem B 2003;107:14336-41. 10. Zakeeruddin SM, Nazeeruddin MK, Humphry-Baker R, Péchy P, Quagliotto P, Barolo C, et al. Design, synthesis, and application of amphiphilic ruthenium polypyridyl photosensitizers in solar cells based on nanocrystalline $\mathrm{TiO}_{2}$ Films. Langmuir 2002;18:952-4.

11. Chen CY, Wu SJ, Wu CG, Chen JG, Ho KC. A ruthenium complex with superhigh lightharvesting capacity for dye-sensitized solar cells. Angew Chem Int Ed 2006;45:5822-5.

12. Chen CY, Chen JG, Wu SJ, Li JY, Wu CG, Ho KC. Multifunctionalized ruthenium-based supersensitizers for highly efficient dye-sensitized solar cells. Angew Chem Int Ed 2008;47:7342-5.

13. Gao F, Wang Y, Shi D, Zhang J, Wang M, Jing X, et al. Enhance the optical absorptivity of nanocrystalline $\mathrm{TiO}_{2}$ film with high molar extinction coefficient ruthenium sensitizers for high performance dye-sensitized solar cells. J Am Chem Soc 2008;130:10720-8.

14. Gao F, Wang Y, Zhang J, Shi D, Wang M, HumphryBaker R, et al. Chem Commun 2008:2635-7.

15. Nazeeruddin MK, Bessho T, Cevey L, Ito S, Klein C, De Angelis F, et al. A high molar extinction coefficient charge transfer sensitizer and its application in dye-sensitized solar cell. $\mathrm{J}$ Photoch Photobio A 2007; 185:331-7.

16. Gao F, Cheng Y, Yu Q, Liu S, Shi D, Li Y, et al. Conjugation of selenophene with bipyridine for a high molar extinction coefficient sensitizer in dye-sensitized solar cells. Inorg Chem 2009;48:2664-9.

17. Jang SR, Yum JH, Klein C, Kim KJ, Wagner P, Officer D, et al. High molar extinction coefficient ruthenium sensitizers for thin film dye-sensitized solar cells. J Phys Chem C 2009;113:1998-2003. 
18. Chen CY, Wang M, Li JY, Pootrakulchote N, Alibabaei L, Ngocle CH, et al. Highly efficient light-harvesting ruthenium sensitizer for thin-film dye-sensitized solar cells. ACS Nano 2009;3:3103-9.

19. Cao Y, Bai Y, Yu Q, Cheng Y, Liu S, Shi D, et al. Dye-sensitized solar cells with a high absorptivity ruthenium sensitizer featuring a 2-(hexylthio)thiophene conjugated bipyridine. J Phys Chem C 2009;113:6290-7.

20. Yu Q, Liu S, Zhang M, Cai N, Wang Y, Wang P. An extremely high molar extinction coefficient ruthenium sensitizer in dye-sensitized solar cells: the effects of $\pi$-conjugation extension. J Phys Chem C 2009;113:14559-66.

21. Kim JJ, Choi H, Kim C, Kang MS, Kang HS, Ko J. Novel amphiphilic ruthenium sensitizer with hydrophobic thiophene or thieno(3,2-b)thiophene-substituted 2,2'-dipyridylamine ligands for effective nanocrystalline dye sensitized solar cells. Chem Mater 2009;21:5719-26.

22. Yu Q, Wang Y, Yi Z, Zu N, Zhang J, Zhang M, et al. High-efficiency dye-sensitized solar cells: the influence of lithium ions on exciton dissociation, charge recombination, and surface states. ACS Nano 2010;4:6032-8.

23. Yen YS, Chen YC, Hsu YC, Chou HH, Lin JT, Yin DJ. Heteroleptic ruthenium sensitizers that contain an ancillary bipyridine ligand tethered with hydrocarbon chains for efficient dye-sensitized solar cells. Chem Eur J 2011;17:6781-8.

24. Chandrasekharam M, Rajkumar G, Srinivasa Rao C, Suresh T, Reddy PY, Soujanya Y. Ruthenium(II)- bipyridyl with extended $\pi$-system: Improved thermo-stable sensitizer for efficient and long-term durable dye sensitized solar cells. J Chem Sci 2011;123:555-65.

25. Huang WK, Wu HP, Lin PL, Diau EWG. Design and characterization of heteroleptic ruthenium complexes containing benzimidazole ligands for dye-sensitized solar cells: the effect of thiophene and alkyl substituents on photovoltaic performance. J Phys Chem C 2013;117:2059-65. 26. Ciana LD, Dressick WJ, Von Zelewsky A. Synthesis of 4,4'-divinyl-2,2'-bipyridine. J Heterocycl Chem 1990;27:163-5. 
27. Giza CA, Hinman RL. New thyroxine analogs. Halogen derivatives of 3-carbethoxy-5-

hydroxy-2-methylbenzofuran. J Org Chem 1964;29:1453-61.

28. Bernatek B, Ledaal T. The reaction between p-benzoquinone and ethyl acetoacetate. Acta Chem Scand 1958;12:2053-4.

29. Wang P, Zakeeruddin SM, Moser JE, Humphry-Baker R, Comte P, Aranyos V, et al. Stable new sensitizer with improved light harvesting for nanocrystalline dye-sensitized solar cells. Adv Mater 2004;16:1806-11. 
PCE $=2.5-2.8 \%$ for $5 \mathrm{~cm}^{2}$ cell
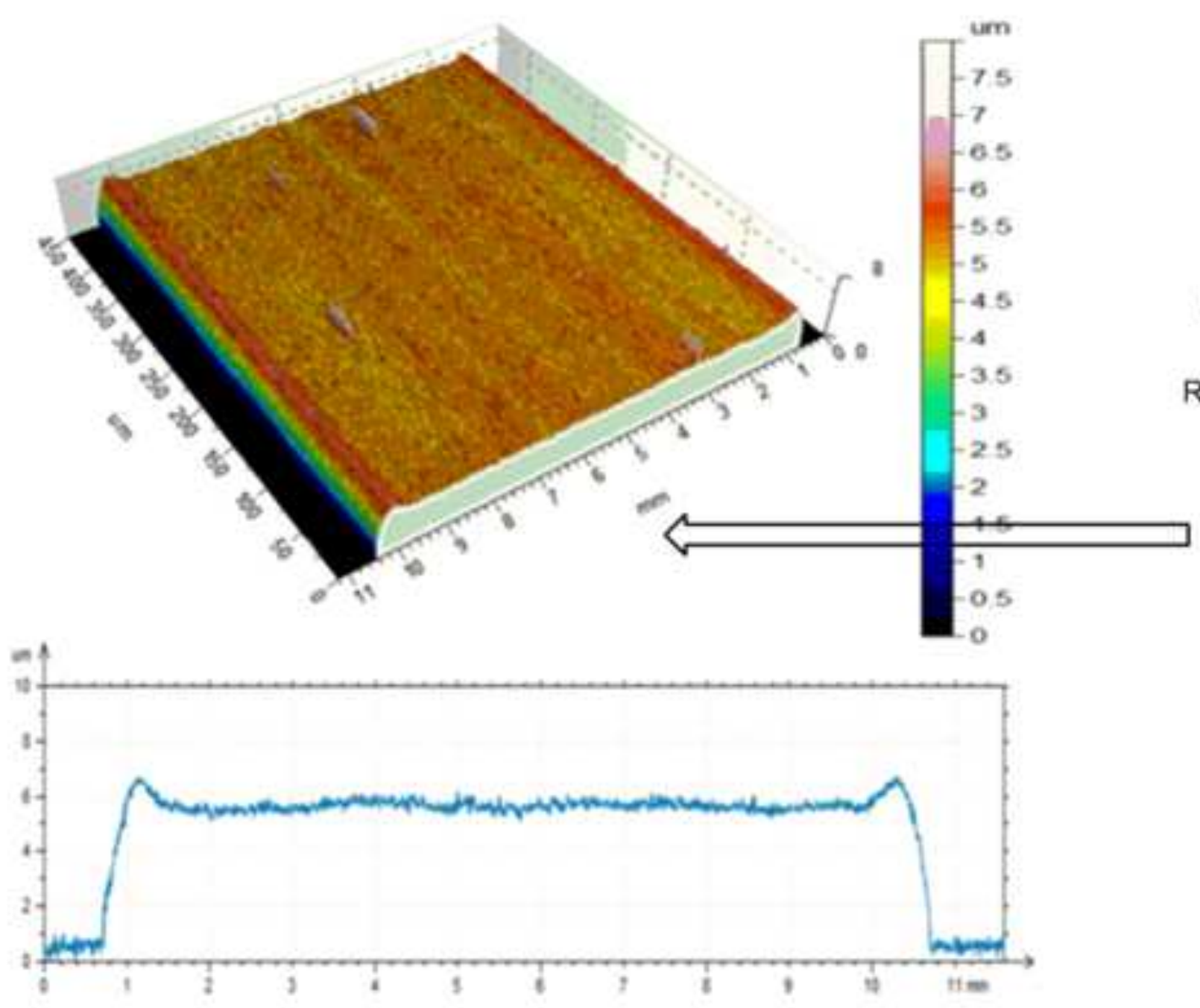

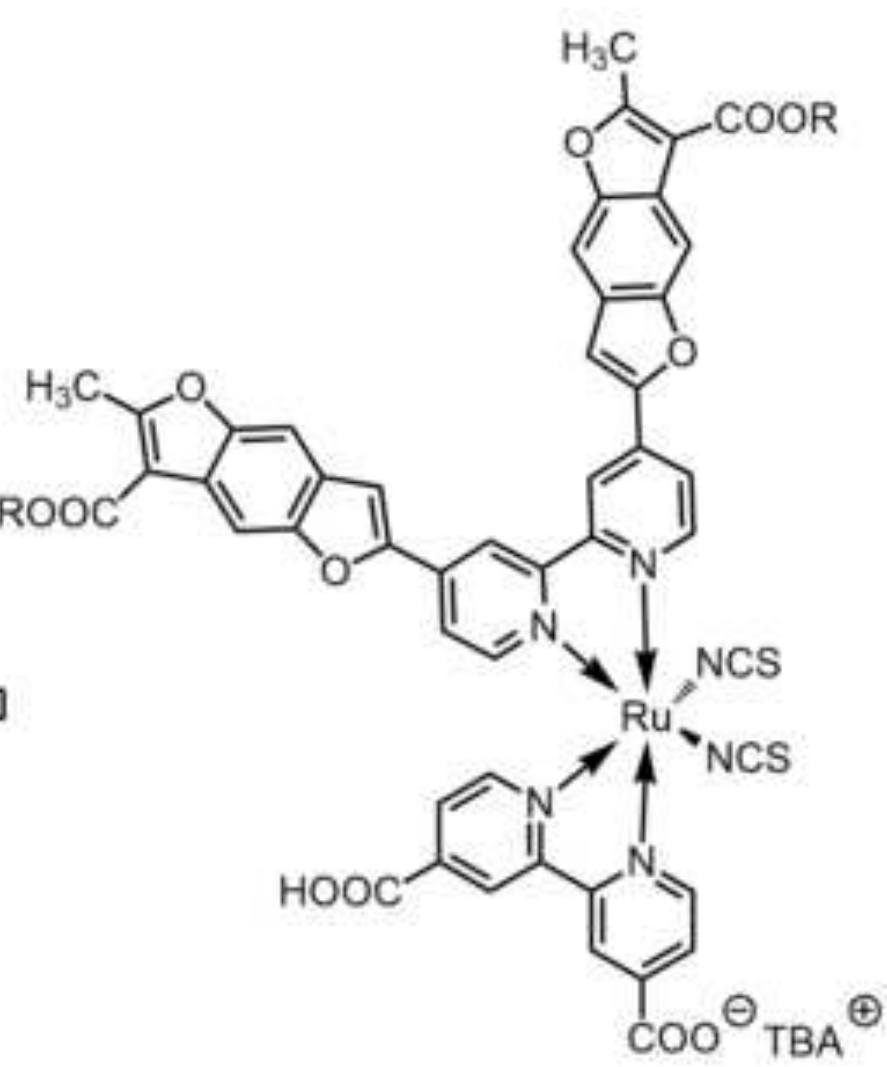

M43, $\mathrm{R}=\mathrm{C}_{8} \mathrm{H}_{17}$

M44, R=Et 
Table 1. Molar absorption coefficients and wavelengths maxima for M43, M44, N719, and Z907 in ethanol

\begin{tabular}{ccc}
\hline Dye & LCCT $\varepsilon\left[\mathrm{M}^{-1} \mathrm{~cm}^{-1}\right] / \lambda_{\max }[\mathrm{nm}]$ & MLCT $\varepsilon\left[\mathrm{M}^{-1} \mathrm{~cm}^{-1}\right] / \lambda_{\max }[\mathrm{nm}]$ \\
$\mathbf{M 4 3}$ & $23200 / 391$ & $13600 / 538$ \\
M44 & $31940 / 377$ & $15800 / 533$ \\
$\mathbf{N 7 1 9}$ & $16000 / 382$ & $13760 / 526$ \\
$\mathbf{Z 9 0 7}$ & $12534 / 411$ & $6440 / 521$ \\
\hline
\end{tabular}


Table 2. Average photovoltaic parameters of the dye-sensitized solar cells with different sensitizers for two dyeing methods

Dip dyeing

\begin{tabular}{cccccccc}
\hline Complex & $\mathrm{V}_{\mathrm{oc}}[\mathrm{mV}]$ & $\mathrm{I}_{\mathrm{sc}}[\mathrm{mA}]$ & $\mathrm{V}_{\mathrm{m}}[\mathrm{mV}]$ & $\mathrm{I}_{\mathrm{m}}[\mathrm{mA}]$ & $\mathrm{P}_{\mathrm{m}}[\mathrm{mW}]$ & $\mathrm{FF}$ & $\eta[\%]$ \\
M43 & 664 & 29.2 & 479 & 26.5 & 12.7 & 0.66 & 2.54 \\
M44 & 666 & 29.7 & 479 & 26.4 & 12.8 & 0.65 & 2.56 \\
N719 & 679 & 24.2 & 511 & 22.2 & 11.3 & 0.69 & 2.26 \\
$\mathbf{Z 9 0 7}$ & 742 & 19.1 & 529 & 17.0 & 8.91 & 0.64 & 1.75 \\
\hline
\end{tabular}

Flow dyeing

\begin{tabular}{cccccccc}
\hline Complex & $\mathrm{V}_{\mathrm{oc}}[\mathrm{mV}]$ & $\mathrm{I}_{\mathrm{sc}}[\mathrm{mA}]$ & $\mathrm{V}_{\mathrm{m}}[\mathrm{mV}]$ & $\mathrm{I}_{\mathrm{m}}[\mathrm{mA}]$ & $\mathrm{P}_{\mathrm{m}}[\mathrm{mW}]$ & $\mathrm{FF}$ & $\eta[\%]$ \\
M43 & 662 & 28.8 & 479 & 26.2 & 12.5 & 0.66 & 2.51 \\
M44 & 670 & 32.7 & 473 & 29.7 & 14.0 & 0.64 & 2.81 \\
$\mathbf{N 7 1 9}$ & 671 & 25.5 & 495 & 23.5 & 11.6 & 0.68 & 2.32 \\
$\mathbf{Z 9 0 7}$ & 764 & 21.2 & 550 & 19.0 & 10.5 & 0.65 & 2.06 \\
\hline
\end{tabular}


figure 1
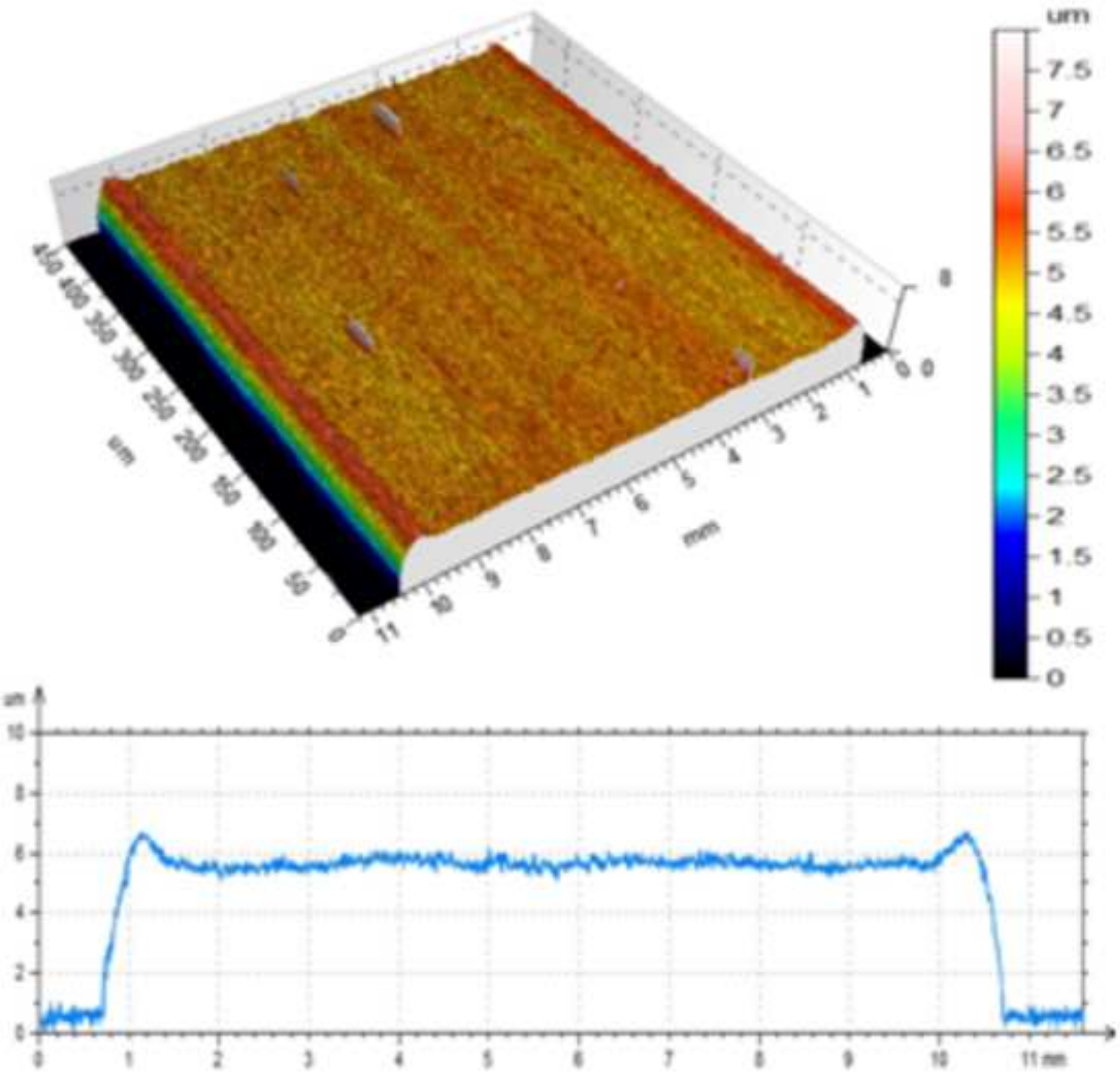
figure 2

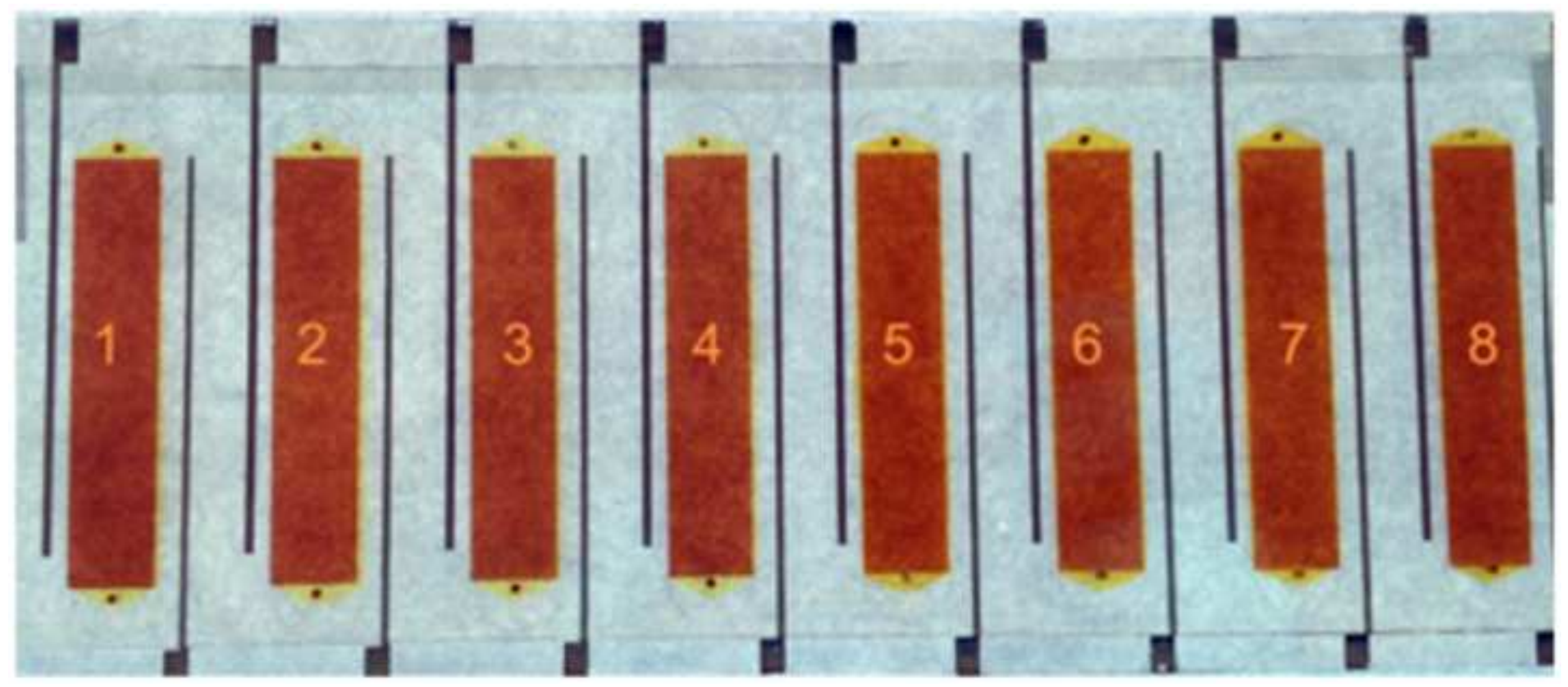


figure 3
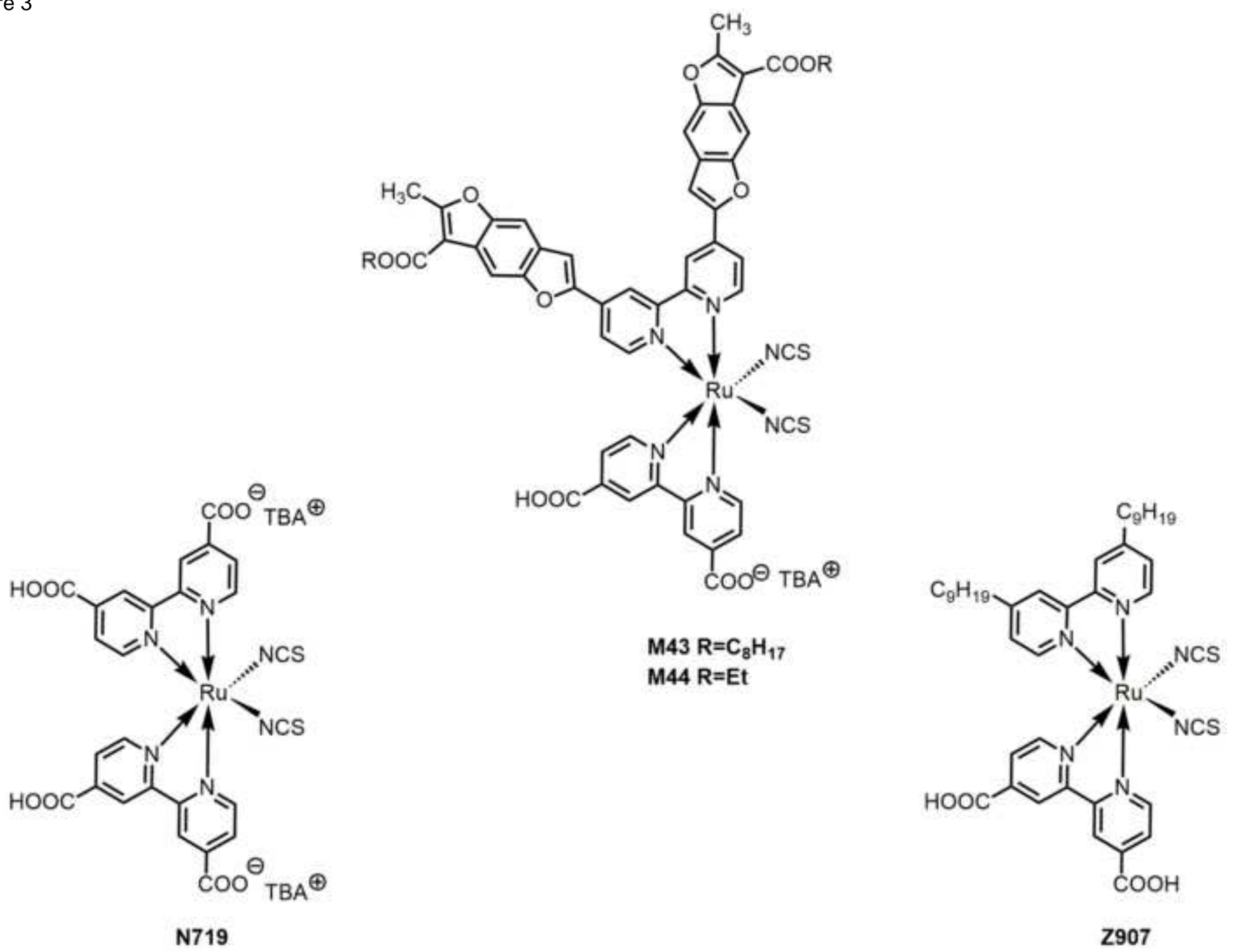
figure 4

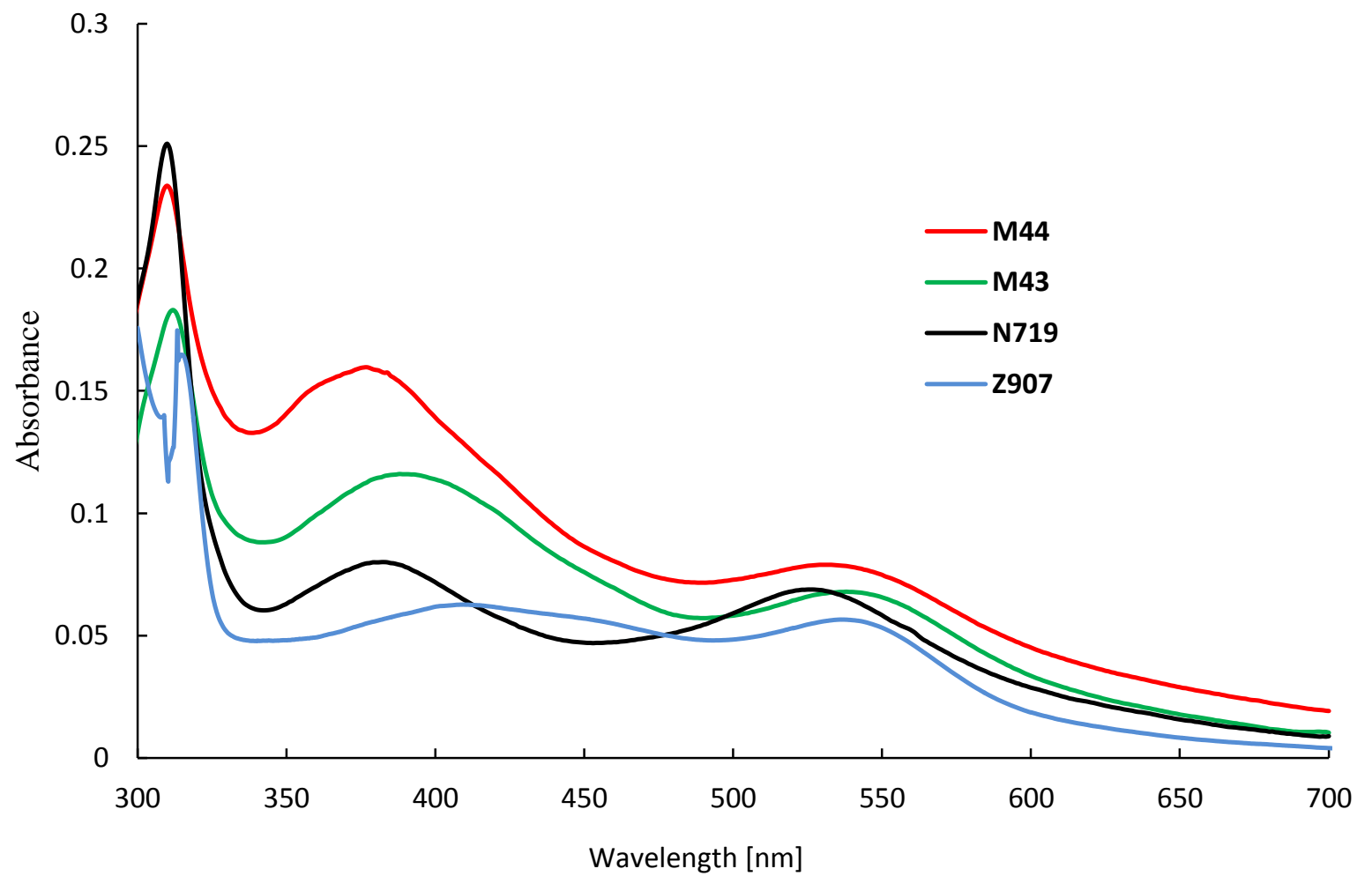


figure 5

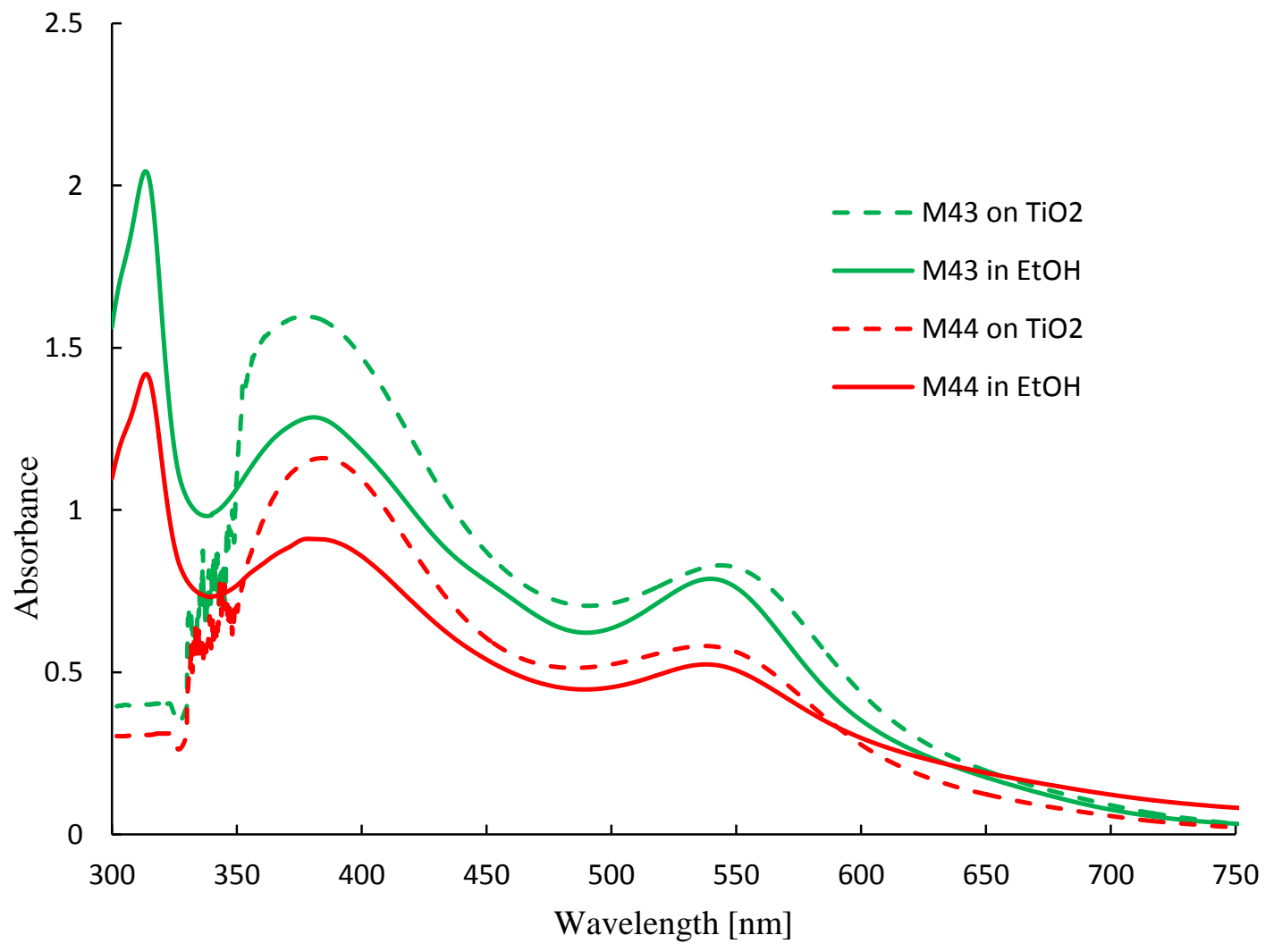


Figure 6

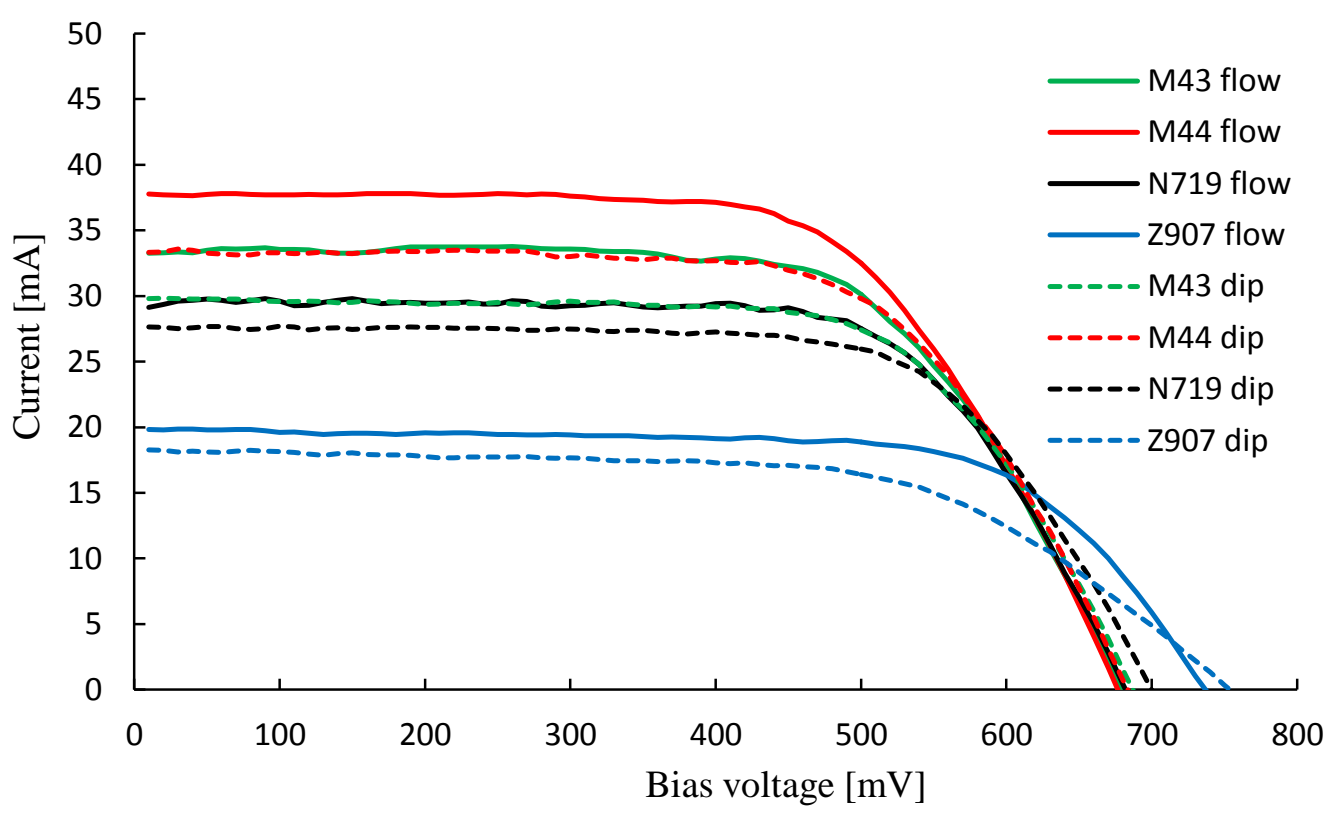


figure 7

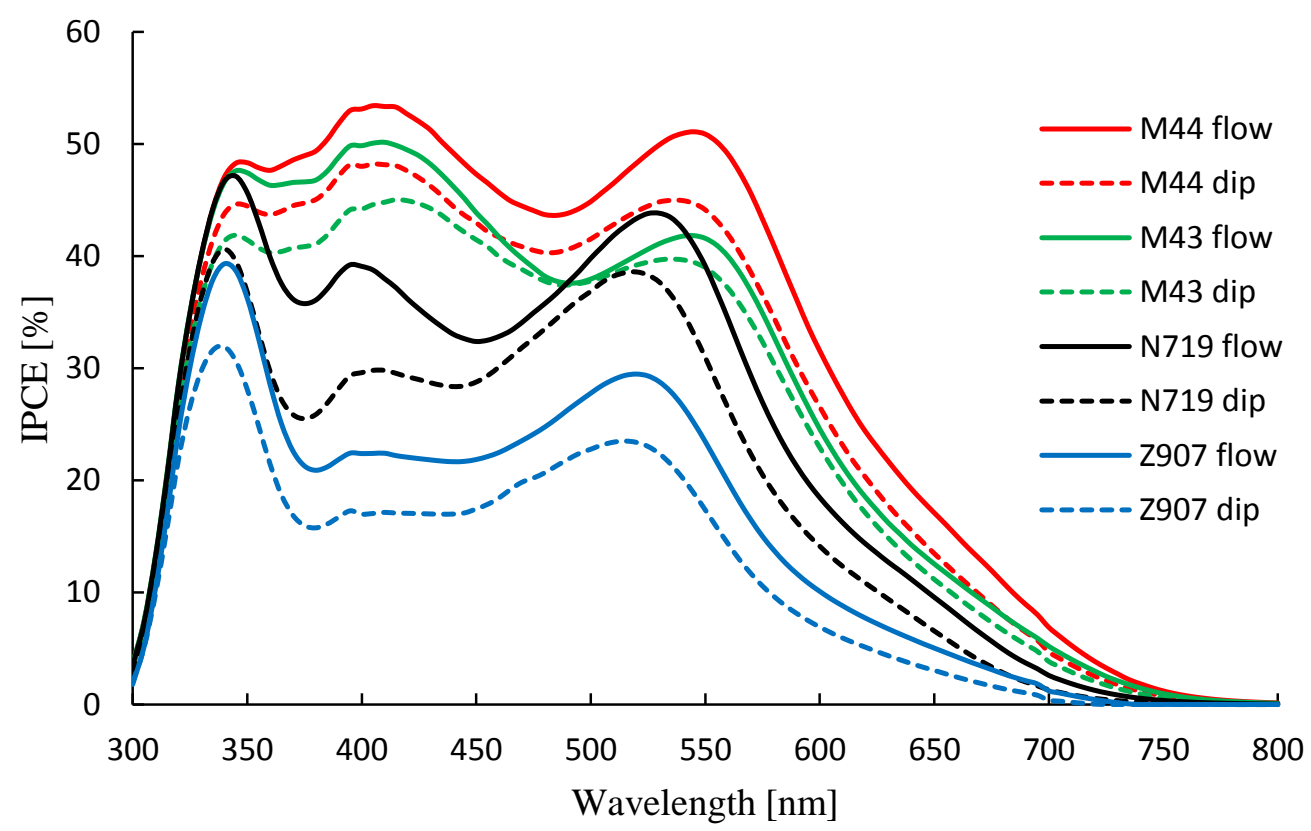

